ESTIMATION OF HYDRAULIC CHARACTERISTICS OF THE UPPER GLACIAL AND MAGOTHY AQUIFERS AT EAST MEADOW, NEW YORK, BY USE OF AQUIFER TESTS

by Keith R. Prince and Brian J. Schneider

U.S. GEOLOGICAL SURVEY

Water-Resources Investigations Report 87-4211

Prepared in cooperation with the

NASSAU COUNTY DEPARTMENT OF PUBLIC WORKS

Syosset, New York 
DEPARTMENT OF THE INTERIOR

MANUEL LUJAN, JR., Secretary

U.S. GEOLOGICAL SURVEY

Dallas L. Peck, Director

For additional information write to:

U.S. Geological Survey

5 Aerial Way

Syosset, NY 11791
Copies of this report may be purchased from:

U.S. Geological Survey Books and Open-File Reports Section Federal Center, Bldg. 41

Box 25425,

Denver, CO 80225 
Abstract. . . . . . . . . . . . . . . . . . . . 1

Introduction. . . . . . . . . . . . . . . . . . . . 1

Purpose and scope. . . . . . . . . . . . . . . . . . 3

Acknowledgments. . . . . . . . . . . . . . . . . . . 3

Geohydrologic setting . . . . . . . . . . . . . . . . . . 3

Regional geohydrology. . . . . . . . . . . . . . . . . 3

East Meadow test site. . . . . . . . . . . . . . . . 4

Aquifer-test design and procedures. . . . . . . . . . . . . . 7

Magothy aquifer test... . . . . . . . . . . . . . . 8

Upper glacial aquifer test . . . . . . . . . . . . . 8

Aquifer-test analysis . . . . . . . . . . . . . . . 12

Analytical methods... . . . . . . . . . . . . . . . . 13

Thiem equation for calculating hydraulic conductivity . . . 13

Specific-capacity method for calculating hydraulic conductivity. . . . . . . . . . . . . . . . . . . . 14

Neuman's delayed yield method for hydraulic conductivity, storage coefficient, and specific yield......... 15

Type-curve analysis. . . . . . . . . . . . . . . . . . 19

Stallman method for calculating hydraulic conductivity and specific yield. . . . . . . . . . . . . . . . 19

Boulton's delayed-yield method for calculating hydraulic conductivity, storage coefficient, and specific yield . . 21

Numerical-model analysis . . . . . . . . . . . . . . . 22

Methods and assumptions............... . 23

Procedures. . . . . . . . . . . . . . . . . 23

Simulation of Magothy aquifer test... . . . . . 24

Simulation of upper glacial aquifer test . . . . . . 25

Results of numerical-model analysis... . . . . . . . 26

Results of aquifer-test analysis. . . . . . . . . . . . . . . 32

Summary and conclusions... . . . . . . . . . . . . . . . . 34

References cited. . . . . . . . . . . . . . . . . . . 34

\section{ILLUSTRATIONS}

Figure 1. Map showing location of study area in central Nassau

County. . . . . . . . . . . . . . . . . .

2. Generalized geologic section of Long Island showing

relative positions of major aquifers. . . . . . . . . .

3. Geologic and gamma-ray logs of an observation well at

the East Meadow test site... . . . . . . . . . . 5

4. Hydrographs of observation wells N9236 and N9225, 1980-85 . 6

5. Hydrographs of observation wells N8959 and N9236 showing regional water levels during the May 1978 and July 1985

aquifer-test periods. 


\section{ILLUSTRATIONS (continued)}

Figure 6. Diagram showing location and depth of wells at Magothy

aquifer test site: A. Plan view. B. Vertical section. .

7. Diagram showing location and depth of wells at upper glacial aquifer test site: A. Plan view. B. Vertical section..................... 10

8. Vertical section of aquifer showing position of observationwell screens and drawdown at end of pumping period:

A. Upper glacial aquifer test. B. Magothy aquifer test. - 16

9. Diagram showing drawdown through time in a pumping well screened in a confined aquifer and a water-table aquifer with delayed gravity drainage... . . . . . . . . .

10. Graphs showing observed drawdowns at four wells screened in the upper glacial aquifer and those computed through

Neuman's delayed-yield method . . . . . . . . . . 18

11. Vertical section of Magothy aquifer test site showing main components, initial values, and corresponding model grid. .

12. Vertical section of upper glacial aquifer test site showing main components, initial values, and corresponding model grid. . . . . . . . . . . . . . . . . . . .

13. Graphs showing observed and simulated drawdowns and recoveries at observation wells in the Magothy aquifer test. . .

14. Graphs showing observed and simulated drawdowns and recoveries at observation wells in the upper glacial aquifer..

\section{TABLES}

Table 1. Selected published estimates of aquifer properties in Nassau County. . . . . . . . . . . . . . . . . . 7

2. Observation-we11 locations and well-screen intervals. . . . 11

3. Results from Stallman type-curve analysis for the upper glacial aquifer test. . . . . . . . . . . . . . 20

4. Results of Boulton delayed-yield type-curve solution for upper glacial aquifer test. . . . . . . . . . . . .

5. Final values used in numerical simulation of Magothy and upper glacial aquifer tests . . . . . . . . . . . . .

6. Summary of hydraulic values obtained through aquifer-test analysis. . . . . . . . . . . . . . . . . . . 


\section{APPENDIXES}

Page

Appendix 1. Data from Magothy aquifer test at East Meadow, May 1978. . 36

2. Data from upper glacial aquifer test, East Meadow, July 1985 . . . . . . . . . . . . . . . . . . 41 


\section{CONVERSION FACTORS AND ABBREVIATIONS}

For the convenience of readers who may prefer to use metric (International System) units rather than the inch-pound units used in this report, values may be converted by using the following factors:

Multiply inch-pound unit

inch (in)

foot $(\mathrm{ft})$ by

\section{Length}

$$
\begin{aligned}
& 25.4 \\
& 0.3048
\end{aligned}
$$

\section{Flow}

foot per day (ft/d)

gallon per minute (gal/min)

gallon per day ( $g a l / d$ )

Million gallons per day

( $\mathrm{Mgal} / \mathrm{d}$ )

$$
\begin{aligned}
& 0.3048 \\
& 0.06308 \\
& 0.003785 \\
& 0.04381
\end{aligned}
$$

millimeter (mm)

meter (m)

\section{Specific capacity}

gallon per minute per

foot $[(\mathrm{gal} / \mathrm{min}) / \mathrm{ft}]$

foot per day ( ft/d)

0.3048

Transmissivity

foot squared per day $\left(f t^{2} / d\right)$

To obtain metric unit

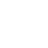




\title{
ESTIMATION OF HYDRAULIC CHARACTERISTICS OF THE UPPER GLACIAL AND MAGOTHY AQUIFERS AT EAST MEADOW, NEW YORK, BY USE OF AQUIFER TESTS
}

\author{
by Keith R. Prince and Brian J. Schneider
}

\begin{abstract}
Drawdown and recovery data from two aquifer tests conducted in central Nassau County were used to calculate aquifer characteristics by six methods to aid in predicting the response of the aquifer sysstem to stress. The first test, on May 12, 1978, entailed pumping the Magothy aquifer for 12 hours; the second, on July 30-31, 1985, entailed pumping the upper glacial aquifer for 24 hours. Drawdown and recovery data from both tests were analyzed by three analytical solutions and two curve-matching procedures, and the resulting hydraulic values were used as initial values in a finite-element radial-flow numerical model to simulate the observed drawdowns and recoveries. Storativity values obtained by all methods were consistent with published estimates, but hydraulic-conductivity values were higher than published estimates. The simple analytical solutions and curve-matching procedures gave reasonable values of most terms quickly, but the estimates made with the finite-element model have the greatest confidence level. This is because the model can represent the aquifer geometry and field conditions of the aquifer tests more accurately than the analytical procedures. These estimates for the Magothy aquifer were: horizontal hydraulic conductivity, 100 feet per day; ratio of horizontal to vertical hydraulic conductivity, 5; and specific storage, $1.0 \times 10^{-4}$. Estimates for the upper glacial aquifer were: horizontal hydraulic conductivity, 380 feet per day; ratio of horizontal to vertical hydraulic conductivity, 2.5 ; and specific yield, 0.15 .
\end{abstract}

\section{INTRODUCTION}

Ground-water contamination has become a major public concern on Long Island since the 1960's. Several studies are being done to assess and predict the movement of ground water and of chemical contaminants, but reliable predictions of contaminant movement can be made only if the transport processes and aquifer characteristics are thoroughly understood. In 1984, the U.S. Geological Survey, in cooperation with Nassau County Department of Public Works, began an investigation of the factors that affect the transport of ground-water solutes at East Meadow, in central Nassau County (fig. 1), where artificial-recharge experiments with reclaimed wastewater had been run since 1982 .

Two aquifer tests were conducted at the East Meadow site. The first entailed pumping water from the Magothy aquifer for 12 hours on May 12, 1978; 
the second test entailed pumping water from the overlying upper glacial (water-table) aquifer for 24 hours on July 30-31, 1985. The purpose of the study was to obtain estimates of the hydraulic properties of the upper glacial and Magothy aquifers in the East Meadow area for use in analyzing the movement of reclaimed wastewater through the aquifer system.

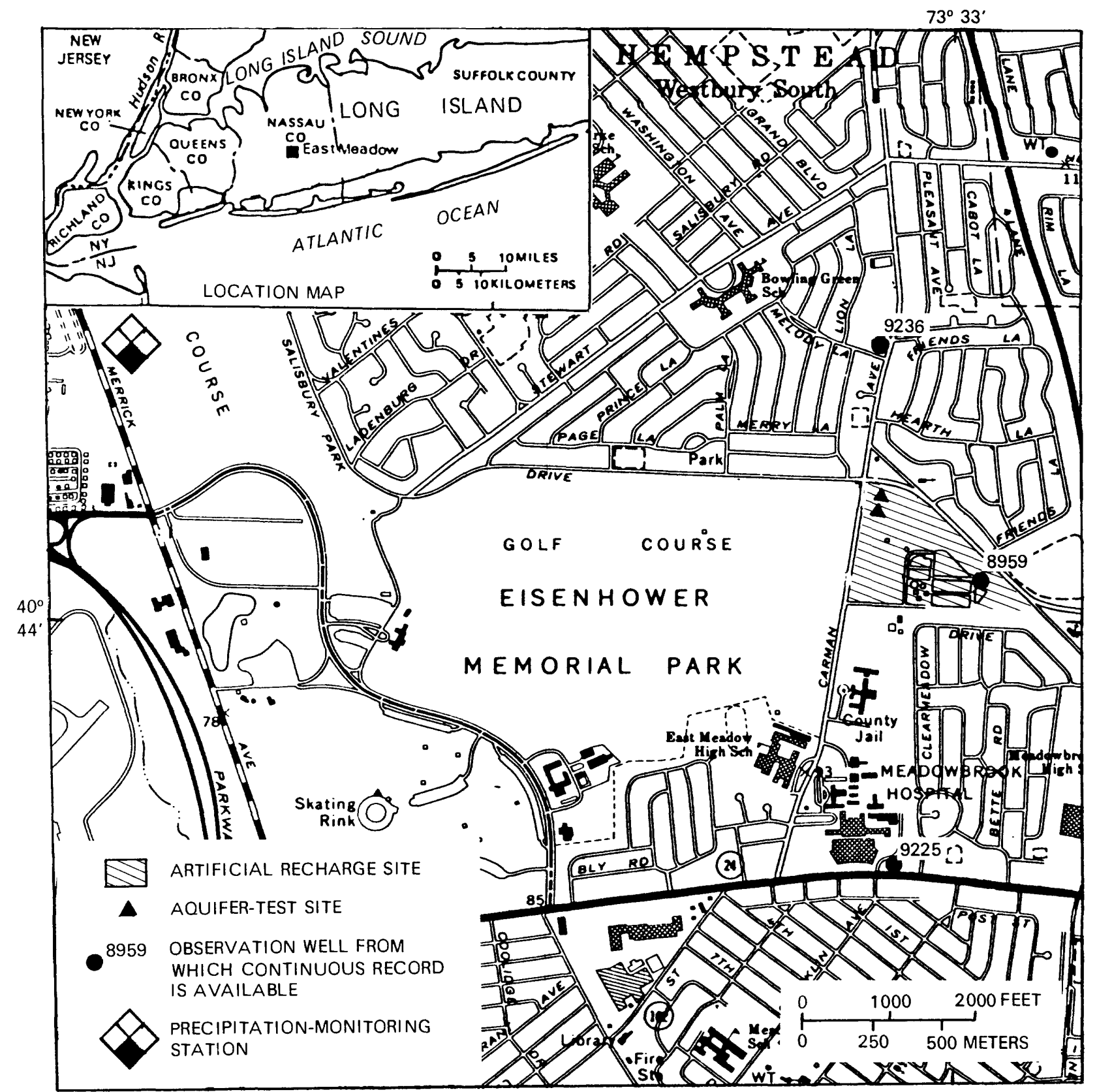

Base from U.S. Geological Survey

Freeport, NY, 1:24,000, 1975

Figure 1.--Location of study area in central Nassau County. 


\section{Purpose and Scope}

This report presents drawdown and recovery data from the two aquifer tests of 1978 and 1985, describes the six methods of analysis used, and summarizes the results of the analyses in tables and graphs.

The drawdown and recovery data were analyzed through three simple analytical equations, two curve-matching techniques, and a finite-element radial-flow model. The analytical techniques included (1) a method based on the Thiem equation (Benta11, 1963; Lohman, 1972), (2) a method that uses the production-well's specific capacity as outlined in Bredehoeft (1963), and (3) an analytical method that accounts for delayed gravity drainage in a water-table aquifer (Neuman, 1975). The curve-matching analysis used type curves developed by R. W. Stallman and delayed-yield type curves developed by Boulton (Lohman, 1972). The resulting estimates of hydraulic conductivity, anisotropy, and storage characteristics were used as initial input values to the finite-element radial-flow model (Reilly, 1984). The flow model was then used to refine the estimates of the aquifer properties by more accurately representing the aquifer geometry and field conditions of the pumping tests.

\section{Acknow ledgments}

The authors thank John F. Caruso, Deputy Commissioner, James F. Mulligan, Peter Witkowski, and Ralph Denton of the Nassau County Department of Public Works for their help in the planning, design, construction, and operation of the aquifer tests. We also thank Thomas E. Reilly of the U.S. Geological Survey for advice and modifications to the radial flow model.

\section{GEOHYDROLOGIC SETTING}

\section{Regional Geohydrology}

Long Island is underlain by a sequence of unconsolidated deposits of sand, gravel, and clay of Quaternary and Late Cretaceous age that unconformably overlie bedrock of schist, gneiss, and granitic rocks of Precambrian age. Many reports detailing the geohydrology of Long Island have been published. Specific information on the island is given by McClymonds and Franke (1972), Franke and McClymonds (1972), and Franke and Cohen (1972). A generalized north-south geologic section through Long Island is given in figure 2.

Overlying the bedrock is the Raritan Formation of Late Cretaceous age, which consists of the lower Lloyd Sand Member (Lloyd aquifer) and the upper clay member (Raritan clay), an effective confining unit.

Overlying the Raritan Formation is the Magothy Formation and Matawan Group, undifferentiated (Magothy aquifer), also of Late Cretaceous age. These deposits consist of clayey and silty fine to medium quartzose sand, some gravel, and clay layers. The Magothy, which is the island's largest aquifer and is used extensively for public supply, is as much as 1,000 ft (feet) thick. The upper surface of the Magothy aquifer is an erosional surface everywhere in Nassau County, including the study area, and is in hydraulic contact with overlying Pleistocene deposits. 


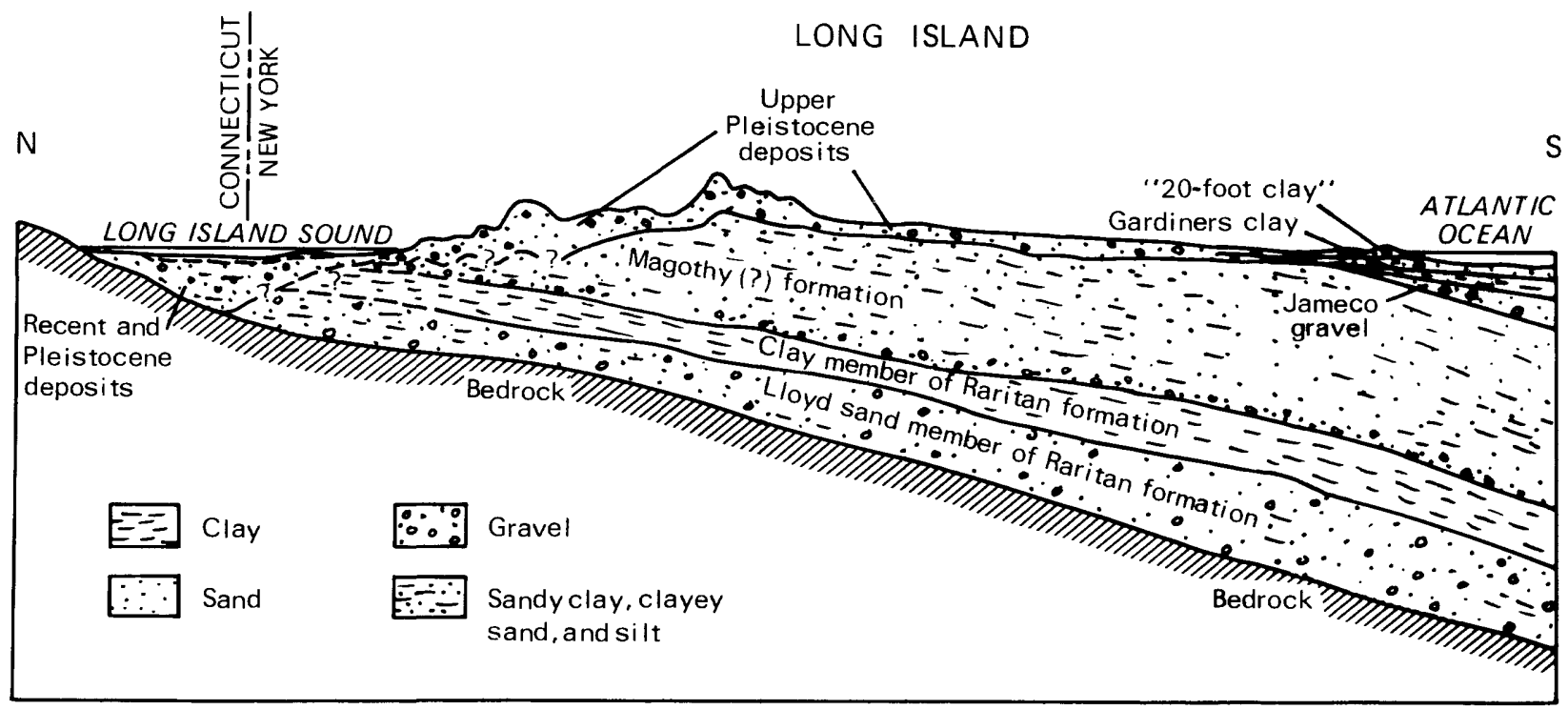

Not to scale Figure 2.--Generalized geologic section of Long Island showing relative
positions of major aquifers. (Modified from Perlmutter and
Geraghty, 1963.)

Overlying the Magothy aquifer are the Pleistocene deposits. Along the south shore of Nassau County, these deposits locally include the Jameco Gravel (Jameco aquifer), which overlies the Magothy aquifer, and an overlying confining unit known as the Gardiners Clay. The Jameco aquifer and Gardiners Clay are absent in the study area. The upper glacial aquifer, which consists mostly of sand and gravel, overlies the Gardiners Clay along the south shore and overlies the Magothy aquifer in the study area. This aquifer contains the water table, which slopes southward at $10 \mathrm{ft} / \mathrm{mi}$ (feet per mile) in the East Meadow area. The upper glacial deposits are generally less than $100 \mathrm{ft}$ thick but may be much thicker where they fill buried valleys or form morainal deposits.

Holocene deposits of swamp bogs, alluvial deposits, lagoonal sediment, and beach and dune sand overlie the Pleistocene deposits along the margins of Long Island in beds generally less than $20 \mathrm{ft}$ thick, but these do not occur in the study area.

\section{East Meadow Test Site}

The East Meadow test site is fairly uniform geologically. Geophysical, lithologic, and drillers' logs obtained during the installation of production and observation wells suggest that the Magothy aquifer consists of a relatively unbroken sequence of interbedded fine to coarse, light-gray sand containing variable amounts of silt and clay. Within these beds are discontinuous lenses of gray clay that contain varying amounts of silt and sand. These lenses are 
laterally discontinuous in this area and are at most $15 \mathrm{ft}$ thick. Beneath the test site, the Magothy aquifer is about $500 \mathrm{ft}$ thick.

Upper glacial aquifer deposits consist of approximately $68 \mathrm{ft}$ of fairly homogeneous medium- to very coarse brownish-orange sand and gravel containing interbedded lenses of fine to medium silty sand and thin beds of sandy clay. A geologists' $\log$ of a 200-ft-deep observation well near the test site and the corresponding gamma-ray $\log$ are shown in figure 3 .

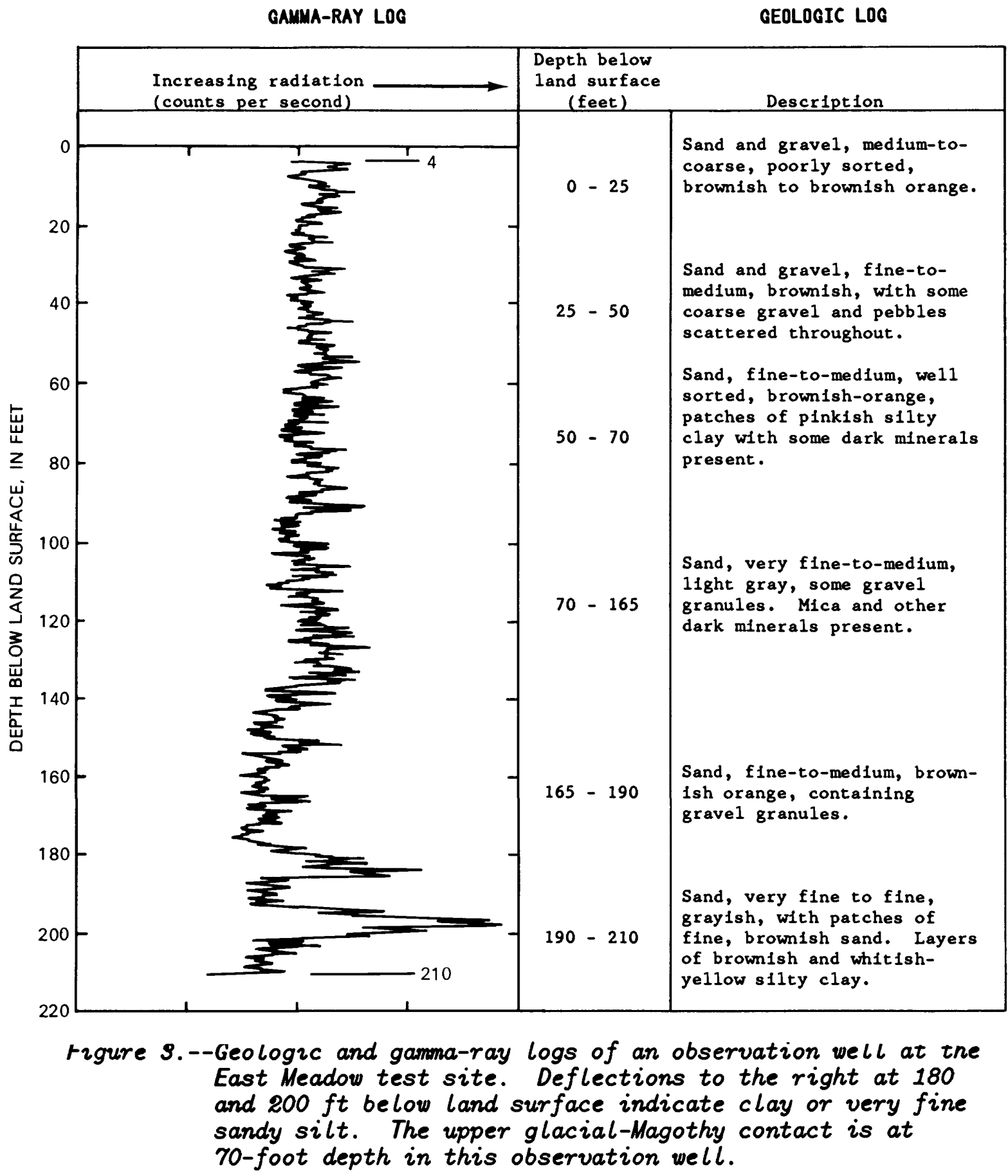


The Pleistocene-Cretaceous contact at the test site is not clearly defined. Aronson and others (1983) delineated the contact on the basis of compositional and textural characteristics; their interpretation was accepted in this study, and the contact is assumed to be $68 \mathrm{ft}$ below land surface or 35 ft above sea level. Depth to water was $35 \mathrm{ft}$ before the Magothy aquifer test in May 1978 and $39 \mathrm{ft}$ before the upper glacial aquifer test in July 1985. Therefore, the saturated thickness of the upper glacial aquifer was $33 \mathrm{ft}$ during the Magothy aquifer test and $29 \mathrm{ft}$ during the upper glacial aquifer test. Ground water in the upper glacial aquifer at the test site is unconfined; that in the Magothy aquifer is unconfined or poorly confined. The degree of confinement in the Magothy generally increases with depth, but ground water moves freely from one aquifer to the other, depending on the hydrostatic head in each aquifer.

Water levels in observation wells at the East Meadow test site have been measured since 1980. Six-year hydrographs for two wells screened in the upper glacial aquifer (fig. 4) show a general decreasing trend during 1980-82, most likely a result of reduced recharge as wastewater was diverted from septic systems to a regional sewer system, completed in 1980, that discharges to tidewater. Measurements made in 1983-84 indicate a rising trend due to precipitation 32 percent above the average $44 \mathrm{in} / \mathrm{yr}$ (inches per year) reported by Miller and Frederick (1969). Most recent measurements indicate that the water table ranges from $55 \mathrm{ft}$ above sea level at the southern limit of the study area to $67 \mathrm{ft}$ above sea level at the northern end. Seasonal pumping for irrigation of a nearby golf course (fig. 1) has caused localized daily water-level fluctuations of as much as $0.1 \mathrm{ft}$.

Hydraulic characteristics of the upper glacial and Magothy aquifers on Long Island have been estimated by several investigatiors; the published values are given in table 1. McClymonds and Franke (1972) used specificcapacity data to estimate the horizontal hydraulic conductivity of the upper glacial and Magothy aquifers in an islandwide investigation. Getzen (1977) made estimates of specific yield, specific storage, and ratios of horizontal to vertical hydraulic conductivity in the upper glacial and Magothy aquifers from results of aquifer tests. Lindner and Reilly (1983) estimated horizontal hydraulic conductivity, ratio of horizontal to vertical hydraulic conductivity, and specific yield of the upper glacial aquifer from results of several aquifer tests conducted along the southern shore of Nassau County.

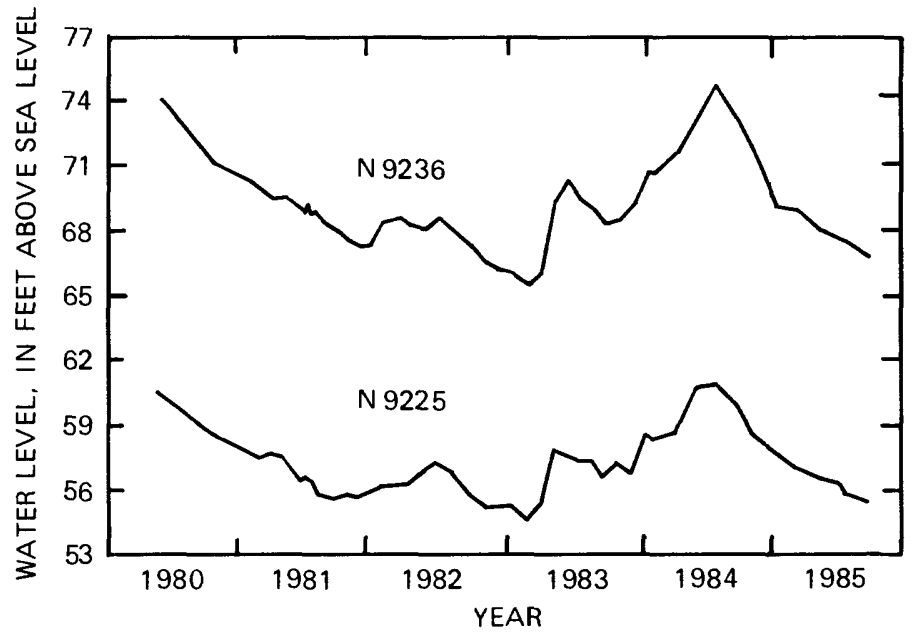

Figure 4.

Hydrographs of observation wells N9236 and N9225, 1980-85. (Locations are shown in fig. 1.) 
Table 1.--Selected published estimates of aquifer properties in Nassau County.

[Dashes indicate no data]

\begin{tabular}{|c|c|c|c|}
\hline $\begin{array}{c}\text { Aquifer } \\
\text { characteristic }\end{array}$ & $\begin{array}{l}\text { Upper } \\
\text { glacial } \\
\text { aquifer }\end{array}$ & $\begin{array}{l}\text { Magothy } \\
\text { aquifer }\end{array}$ & Data Source \\
\hline $\begin{array}{l}\text { Horizontal hydraulic } \\
\text { conductivity (ft/d) }\end{array}$ & $\begin{array}{l}270-335 \\
140-380\end{array}$ & $\begin{array}{c}50-70 \\
--\end{array}$ & $\begin{array}{l}\text { McClymonds and Franke (1972) } \\
\text { Lindner and Rellly (1983) }\end{array}$ \\
\hline $\begin{array}{l}\text { Ratio of horizontal to } \\
\text { vertical hydraulic } \\
\text { conductivity }\end{array}$ & $\begin{array}{l}2.4-16 \\
1.8-24\end{array}$ & $30-60$ & $\begin{array}{l}\text { Lindner and Re11ly (1983) } \\
\text { Getzen (1977) }\end{array}$ \\
\hline $\begin{array}{l}\text { Specific yield } \\
\text { (dimensionless) }\end{array}$ & $\begin{array}{c}0.13-0.24 \\
0.18\end{array}$ & -- & $\begin{array}{l}\text { Lindner and Reilly (1983) } \\
\text { Getzen (1977) }\end{array}$ \\
\hline Specific storage $\left(f t^{-1}\right)$ & -- & $\begin{array}{ll}3 \times 10^{-5} \\
3 \times 10^{-6}\end{array}$ & Getzen (1977) \\
\hline
\end{tabular}

\section{AQUIFER-TEST DESIGN AND PROCEDURES}

The Magothy aquifer test differed from the upper glacial aquifer test in production-well design, observation-well locations, methods of drawdown and recovery measurement, pumping rates, and test duration. Both received precipitation 3 days before the test; 1.1 inches of rain fell on May 9, 1978, 3 days before the Magothy aquifer test, and 2.2 inches fell on July 27, 1985, 3 days before the upper glacial aquifer test. Two wells screened in the upper glacial aquifer near the aquifer-test site were continuously monitored before, during, and after the tests to reveal any regional trends in water levels as a result of natural or man-induced stress. Hydrographs (fig. 5) indicate waterlevel changes of less than $0.10 \mathrm{ft}$ throughout the testing periods. (Locations of wells, test site, and the precipitation station are given in fig. 1.) None of the methods used in the aquifer-test analyses account for recharge from precipitation, but this was not a problem because the hydrographs (fig. 5) indicate that neither storm had a significant effect on water levels at the site.
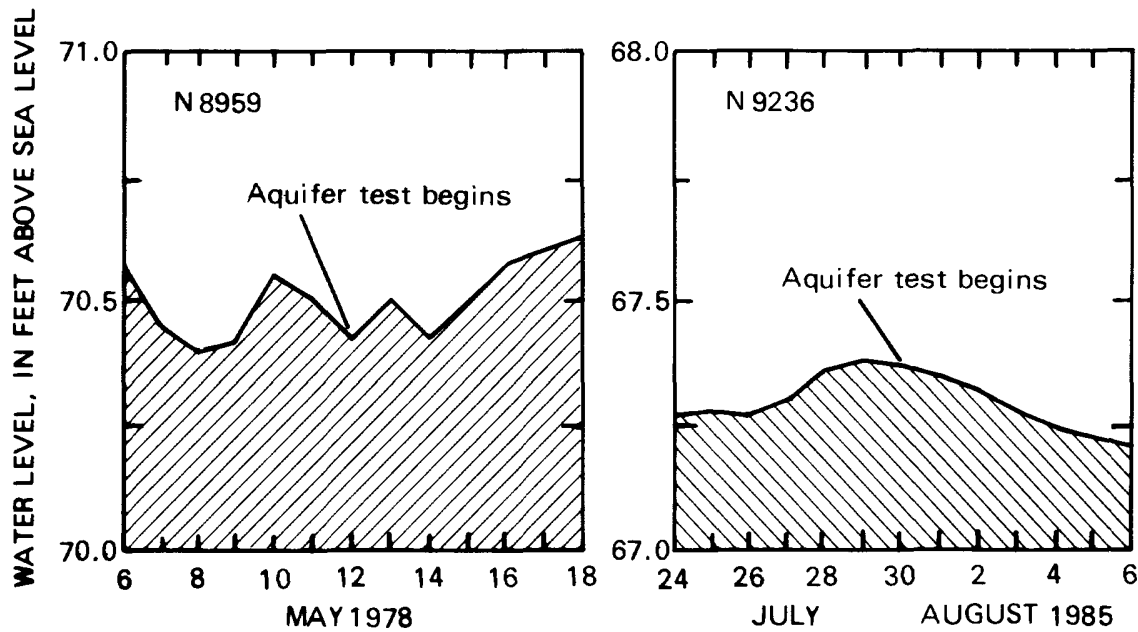

Figure 5 .

Hydrographs of observation wells N8959 and N9236 showing regional water levels during the May 1978 and July 1985 aquifertest periods. (Locations are shown in fig. 1.) 


\section{Magothy Aquifer Test}

The production well used during the Magothy aquifer test had been designed and used as an injection well throughout a series of artificialrecharge experiments during 1982-84. Because the upper 3 or $4 \mathrm{ft}$ of this well screen taps the upper glacial aquifer, it was not ideal for aquifer-test analysis. The well is $95 \mathrm{ft}$ deep and contains $65 \mathrm{ft}$ of 12-in.-diameter fiberglass casing and a 30-ft length of 60-slot stainless-steel screen affixed below. The well was pumped during the test by a turbine pump with the intake set $75 \mathrm{ft}$ below land surface.

Nearby observation wells, which had been installed to monitor water-level changes resulting from artificial recharge, were also used to monitor drawdown and recovery during the pumping test. The locations and depths of wells at the Magothy aquifer-test site (fig. 1) are shown in plan view and vertical sections in figure 6 and summarized in table 2 (p. 11). The test site had four sets of fiberglass-cased observation wells drilled in a line from the pumping we11, with either two or three wells to a set. The first set, approximately $8 \mathrm{ft}$ from the pumping well, consisted of a 3-in.-diameter well with a 5-ft screen just below the water table and a 6-in.-diameter well with a 5-ft screen directly opposite the pumping well screen. The second set, 26 ft from the pumping well, consisted of two 6-in.-diameter wells, 45 and $105 \mathrm{ft}$ deep. Each had a 5-ft section of screen. The remaining two sites were triads, 100 and $525 \mathrm{ft}$ from the pumping well, consisting of 6-in.-diameter wells with 5-ft screen sections. One well screen in each set was just below the water table, 40 to $45 \mathrm{ft}$ below land surface; another was screened deeper than the pumpingwell screen, about $100 \mathrm{ft}$ below land surface, and the third was screened 195 to $200 \mathrm{ft}$ below land surface (fig. 6). Other observation wells screened in the upper glacial and Magothy aquifers in the study area were used to monitor ambient conditions. One disadvantage to placing the observation wells along a line was the lack of observation points in other radial directions, which led to difficulty in verifying radially symmetric flow.

Starting at 0700 hours on May 12, 1978, the production well was pumped for 12 consecutive hours. The pumping rate was $750 \mathrm{gal} / \mathrm{min}$ (gallons per minute) and varied by no more than 3 percent, as measured by manometer. Drawdowns in all wells were measured with chalked steel tapes or drop lights. Water-level measurements were taken during 12 hours of pumping and the following 12 hours of recovery. Drawdown and recovery data from the Magothy aquifer test are listed in appendix 1 (p. 34).

\section{Upper Glacial Aquifer Test}

The site plan for the upper glacial aquifer test was designed to fit the assumptions in Stallman's method of pumping-test analysis (Lohman, 1972), as outlined in the later section "Stallman Type-Curve Analysis." The design included (1) installing the production well such that the well screen tapped the bottom third of the saturated thickness of the aquifer, and (2) placing all observation wells but one in a line south of the production we11; the one well was placed 30 feet from the production well at right angles to the line of observation wells to obtain information on radial symmetry of flow. 
The production well was $67 \mathrm{ft}$ deep and consisted of $55 \mathrm{ft}$ of 8-in.-diameter PVC casing and a 12-ft section of 80-slot stainless-stee 1 screen from the 55-to-67-ft depth. Cement grout was used to seal the annular space below the production-well screen. A 2-in. PVC observation well was installed within the annular space with a $10 \mathrm{ft}$ section of screen placed 55 to $65 \mathrm{ft}$ below land surface. The annular space around both well screens was backfilled with a mixture of No. 2 and no. 3 sorted gravel. The remaining annular space above the production-well and observation-well screens was backfilled with unconsolidated material and cuttings from the reverse rotary-drilling process. A submersible pump was installed in the production well with the intake opposite the middle of the well screen.

The horizontal position and depths of wells in the upper glacial aquifer test are depicted in $\mathrm{plan}$ view and vertical sections in figures $7 \mathrm{~A}$ and $7 \mathrm{~B}$ and summarized in table 2 ( $p .11)$. In addition to the production well, the test

A
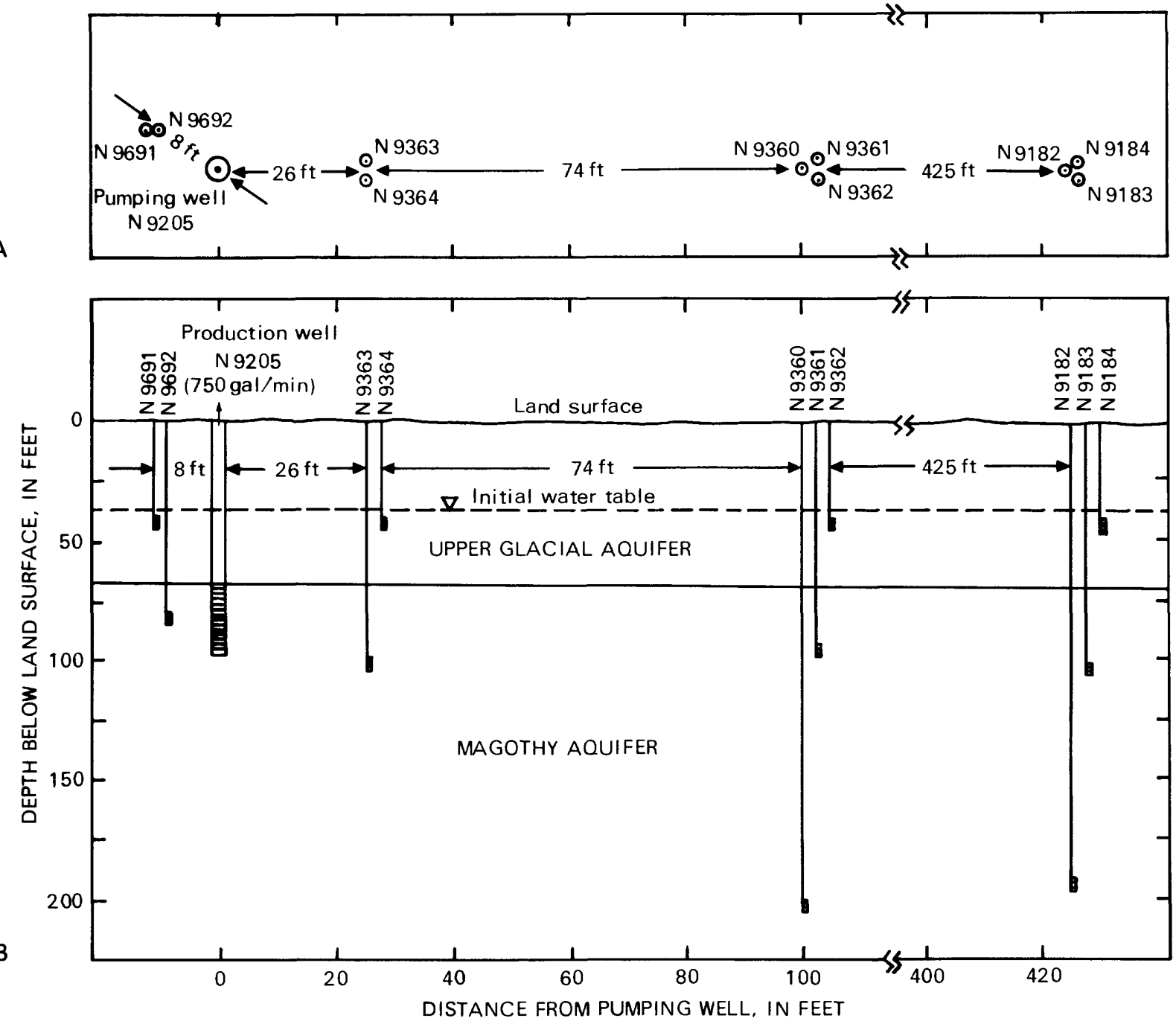

Figure 6.--Location and depth of wells at Magothy aquifer-test site: A. Plan view. B. Vertical section. 
site contained three observation-well sets, each with one, two, or three 4-in.-diameter PVC wells that were drilled by auger. The first set, $30 \mathrm{ft}$ from the pumping we11, was a triad of wells 45, 64, and $108 \mathrm{ft}$ deep. The second set, $60 \mathrm{ft}$ and collinear from the production well, consisted of two wells 45 and $64 \mathrm{ft}$ deep. The third set, $30 \mathrm{ft}$ from the well 1 ine and perpendicular to it at the production well, consisted of one well $64 \mathrm{ft}$ deep. Each well contained a 5-ft section of screen at the bottom, and each was backfilled with drill cuttings. Upon completion of drilling, all wells were developed for several hours. Each well was equipped with a continuous-reading analog water-level recorder with which drawdown and recovery were recorded.

Water-level measurements were begun at the production well and the observation wells 48 hours before the start of the test. Other observation wells beyond the test site were also monitored to detect regional responses to the test. The pumping rate was set at $500 \mathrm{gal} / \mathrm{min}$ to ensure submergence of

A
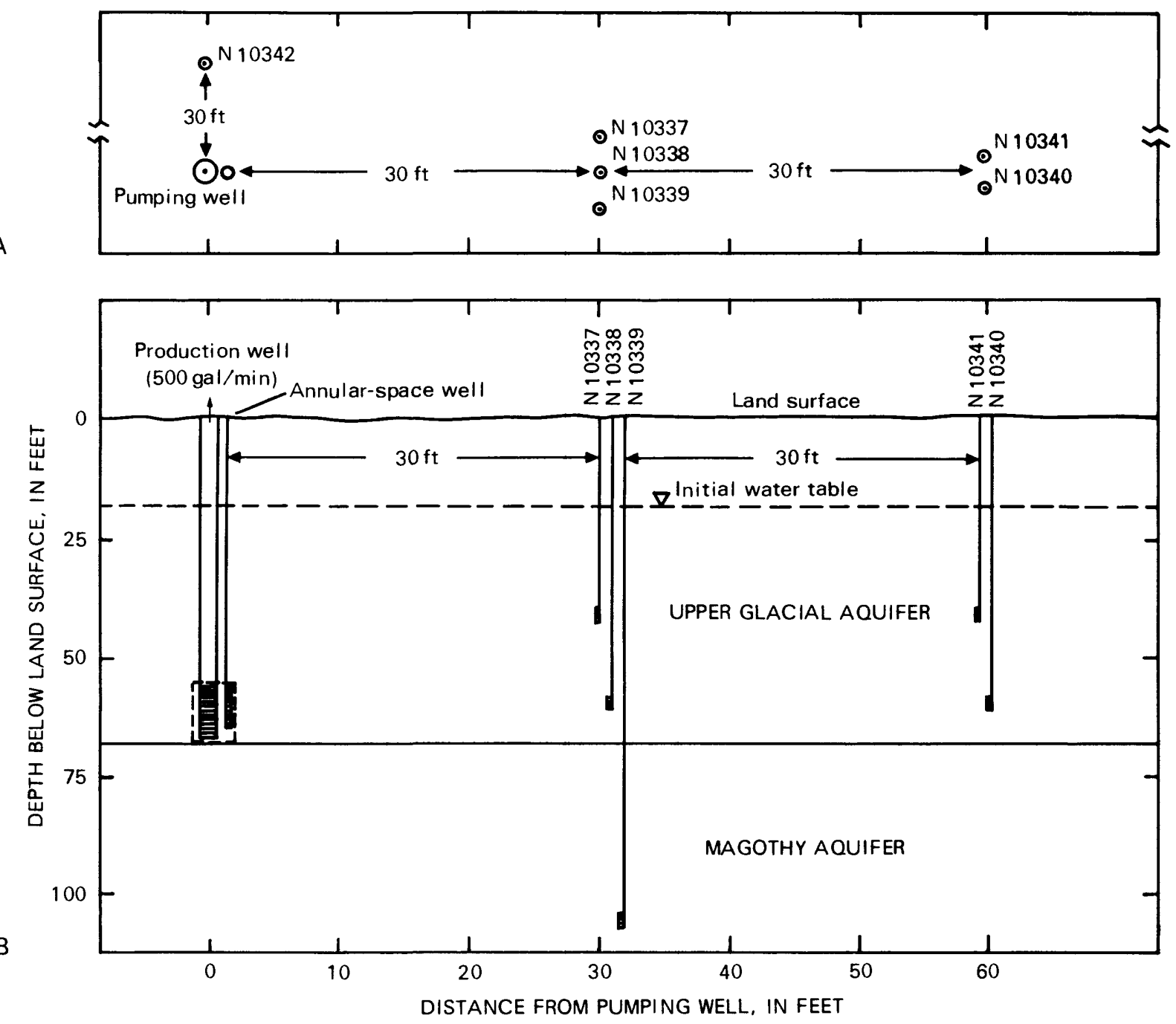

Figure 7.--Location and depth of wells at upper glacial aquifer test site: A. Plan view. B. Vertical section. 
the entire production-well screen during pumping; also, water levels in the annular-space well and production well were monitored periodically during the test to ensure complete submergence of the production-well screen. Flow rate, as measured through a 5-in.-orifice plate, fluctuated by no more than 2 percent throughout the 24-hr pumping period.

The production well was pumped for 24 hours starting at 0815 hours on July 30, 1985 and tick marks were put on the continuous-recording water-level charts at each observation well at specified intervals. The production well and annular-space well were measured for drawdown at the same time intervals with an electric tape to ensure that the production well screen remained fully submerged. After 24 hours, the pump was shut off, and recovery measurements were made at the same time intervals as during the pumping phase of the test. Drawdown and recovery data from the upper glacial aquifer test are listed in appendix 2 (p. 39).

Table 2.--Observation-well locations and well-screen intervals.

[Dash indicates well not present in aquifer unit.]

\begin{tabular}{|c|c|c|c|}
\hline & & Depth of & $\begin{array}{l}\text { Distance from top of } \\
\text { Magothy aquifer }\end{array}$ \\
\hline $\begin{array}{c}\text { Well } \\
\text { number }\end{array}$ & $\begin{array}{c}\text { Distance from } \\
\text { pumping well } \\
\text { (feet) }\end{array}$ & $\begin{array}{c}\text { screen below } \\
\text { water table } \\
\text { (feet) }\end{array}$ & $\begin{array}{l}\text { Below } \\
\text { (feet) }\end{array}$ \\
\hline
\end{tabular}

A. Magothy Aquifer-Test Site

[Positions and depths are shown in fig. 6]

\begin{tabular}{|c|c|c|c|c|c|}
\hline N9691 & 8 & $5-10$ & $23-28$ & & -- \\
\hline N9692 & 8 & $45-50$ & -- & & $12-17$ \\
\hline N9363 & 26 & $65-70$ & -- & & $32 \quad 37$ \\
\hline N9364 & 26 & $5-10$ & $23-28$ & & -- \\
\hline N9360 & 100 & $165-170$ & -- & & $132-137$ \\
\hline N9361 & 100 & $58-63$ & -- & & $25-30$ \\
\hline N9362 & 100 & $5-10$ & $23-28$ & & -- \\
\hline N9182 & 525 & $156-161$ & -- & & $123-128$ \\
\hline N9183 & 525 & $66-71$ & -- & & $33-38$ \\
\hline N9 184 & 525 & $5-10$ & $23-28$ & & -- \\
\hline N9205 (Pumping wel1) & -- & $30-63$ & 3 & to & 30 \\
\hline \multicolumn{6}{|c|}{$\begin{array}{l}\text { B. Upper Glacial Aquifer-Test Site } \\
\text { [Positions and depths are shown in fig. 7] }\end{array}$} \\
\hline Annular space well & 0 & $16-26$ & $3-13$ & & -- \\
\hline N10342 & 30 & $19-24$ & $5-10$ & & -- \\
\hline N10337 & 30 & $0-5$ & $24-29$ & & -- \\
\hline N10338 & 30 & $19-24$ & $5-10$ & & - \\
\hline N10339 & 30 & $65-70$ & -- & & $36-41$ \\
\hline N10341 & 60 & $0-5$ & $24-29$ & & -- \\
\hline N10340 & 60 & $19-24$ & $5-10$ & & -- \\
\hline N10366 (Pumping wel1) & -. & $16-28$ & $1-13$ & & $\ldots$ \\
\hline
\end{tabular}




\section{AQUIFER-TEST ANALYSIS}

The two aquifer tests were analyzed by five methods, described below, to obtain initial estimates of aquifer properties for use in a numerical-model analysis of both aquifer tests.

(1) The simplest method was an analytical solution for hydraulic conductivity that is equivalent to the Thiem equation and is based on the Dupuit assumption (Benta11, 1963).

(2) A method described by McClymonds and Franke (1972) was used to calculate hydraulic conductivity of the upper glaclal aquifer from specific-capacity data obtained from the production well.

(3) An analytical method that characterizes the delayed gravity drainage or delayed-yield response of wells in unconfined aquifers developed by Neuman (1975) was also used to estimate hydraulic conductivity and both specific storage and specific yield of the upper glacial aquifer.

(4) A curve-fitting procedure developed by Stallman (Lohman, 1972) was used to estimate horizontal and vertical hydraulic conductivity and storage.

(5) A second curve-fitting procedure, which uses a family of type curves that take into account the delayed yield from storage in unconfined aquifers (Boulton, 1963), was also used to estimate horizontal and vertical hydraulic conductivity and storage.

Use of the three analytical solutions to evaluate aquifer-test results can quickly yield adequate estimates of aquifer properties. Application of these techniques to these aquifer tests is not rigorously correct, however, because the aquifer geometry, partial penetration of the production well in the Magothy aquifer, location of observation wells, and boundary conditions violate some of the assumptions on which the analytical solutions are based.

The Magothy aquifer test, for example, used a well placement that had been originally designed for artificial-recharge experiments with reclaimed wastewater; therefore the well screens were not positioned vertically to meet the assumptions of the analytical or curve-matching analysis procedures. In addition, nearly $4 \mathrm{ft}$ of the $30-\mathrm{ft}$ production-well screen was open to the upper glacial aquifer, which means that the water-level response would be heavily influenced by the upper glacial aquifer's characteristics. Although all test-analysis techniques mentioned above were applied to the Magothy aquifer test data, two of them (specific-capacity data and type-curve analysis) yielded unreasonable hydraulic-conductivity values, probably because the production well taps two aquifers with differing hydraulic properties.

The analytical methods described in the following sections were used to generate initial estimates of aquifer properties for use in the numerical model analysis of both aquifer tests. The chief advantages in using the numerical model for pumping-test analysis are that it can (1) simulate the geologic environment in detail; (2) calculate drawdown and recovery curves for all observation wells simultaneously; and (3) provide estimates of horizontal and vertical hydraulic conductivity and storage characteristics of more than one aquifer at a time. 


\section{Analytical Methods}

Three analytical methods were used to estimate aquifer hydraulic conductivity and storage properties. The chief advantage of these methods is the ease with which they can be applied and with which the resulting equations can be solved. The results of the analytical methods are somewhat less reliable than those obtained from more rigorous analysis technique owing to the conceptually simpler system and simpler assumptions upon which they are based, as outlined below. These analytical methods avoid the somewhat subjective comparison of observed drawdown curves with type curves or calculated drawdown curves. The third analytical method, that of Neuman (1975), was developed from a more complex concept of aquifer response to stress and is also more complex in its application in that it requires simultaneous estimates for several hydraulic factors. Analyzing the aquifer tests by the Neuman method requires an iterative technique in which the generated drawdown curves are compared with observed drawdown curves. The three analytical methods used for analysis are described below.

\section{Thiem Equation for Calculating Hydraulic Conductivity}

A form of the Thiem equation presented in Bentall (1963) and Lohman (1972) was used to calculate hydraulic conductivity of the Magothy aquifer:

$$
K=-\frac{2.3 Q \log _{10}\left(r_{2} / I_{1}\right)}{\pi\left(h_{2}^{2}-h_{1}^{2}\right)}
$$

where: $\quad K=$ hydraulic conductivity, in $\mathrm{ft} / \mathrm{d}$;

$Q=$ pumping rate, in $\mathrm{ft}^{3} / \mathrm{d}$

$r_{1}, r_{2}=$ distance of well 1 or 2 from the pumping well, in $\mathrm{ft}$; and $h_{1}, h_{2}=$ head in well 1 or 2 above the aquifer base, in $\mathrm{ft}$.

Computations for thin, unconfined aquifers like the upper glacial aquifer in the East Meadow area require correction for the decreasing saturated thickness as the water table is drawn down around the pumping well. The hydraulic conductivity of the upper glacial aquifer was estimated from the form of the Thiem equation that corrects for changes in saturated thickness. The equation, which was modified from the Thiem equation by Jacob and presented in Lohman (1972, p. 12) is:

$$
K=-\frac{2.3 Q \log _{10}\left(r_{2} / r_{1}\right)}{2 \pi b\left[\frac{\left(b^{2}-2 b s_{2}+s_{2}^{2}\right)-\left(b^{2}-2 b s_{1}+s_{1}^{2}\right)}{2 b}\right]}
$$

where: $\quad K, Q, r_{1}$ and $r_{2}$ are as above; and

$\mathrm{b}=$ initial aquifer thickness, in $\mathrm{ft}$;

$s_{1}, s_{2}=$ water-table drawdown in well 1 or 2 , in $\mathrm{ft}$. 
Jacob's analytical solution as presented in Bentall (1963) is based on the assumption of steady radial flow in an isotropic and homogeneous aquifer with an impermeable base; it also assumes a lack of vertical head gradients (the Dupuit assumption) and a fully penetrating production well. For purposes of this analysis, the assumption was made that all release from storage within a 100-ft radius of the production well had ceased by the end of the pumping period, which partly fulfilled the requirements for steady-state flow. The observed drawdown at each observation well at the end of the pumping period in both tests is indicated in the two vertical sections in figure 8 ( $p .16)$.

The observed drawdowns at wells $\mathrm{N} 9361$ and $\mathrm{N} 9363$ (appendix 1), combined with an initial Magothy aquifer thickness of $489 \mathrm{ft}$, indicated the hydraulic conductivity of the Magothy aquifer to be $25 \mathrm{ft} / \mathrm{d}$ (feet per day). Similarly, the drawdowns at wells $\mathrm{N} 10337$ and N10341 (appendix 2), combined with an initial saturated thickness of $29 \mathrm{ft}$, indicated the hydraulic conductivity of the upper glacial aquifer to be $510 \mathrm{ft} / \mathrm{d}$.

The calculated hydraulic conductivity of the Magothy aquifer, $25 \mathrm{ft} / \mathrm{d}$, is much lower than expected, probably because the well locations and screened intervals of the field installation differed considerably from the ideal configuration for application of the Thiem equation. The partially penetrating production well, combined with the shallow screened interval and considerable aquifer heterogeneity, contributed to the poor estimate of hydraulic conductivity.

In the upper glacial aquifer test, the maximum vertical head difference at the end of the pumping cycle was $0.34 \mathrm{ft}$ at the observation wells $30 \mathrm{ft}$ from the production well. The vertical gradient of $0.02 \mathrm{ft} / \mathrm{ft}$ was relatively large compared to the horizontal gradient of 0.026 at the water table and 0.030 at the base of the upper glacial aquifer aquifer. This analysis technique assumes a lack of vertical gradients, but the vertical gradients measured are of the same magnitude as the horizontal gradients, which indicates one source of error in the analysis. Another source is the lack of an impermeable boundary at the base of the upper glacial aquifer. Although the Magothy and upper glacial aquifers are in good hydraulic connection, which tends to skew the calculated hydraulic-conductivity values of both aquifers upward, the other sources of error discussed above seem to have far outweighed these effects.

\section{Specific-Capacity Method for Calculating Hydraulic Conductivity}

Hydraulic conductivity of the upper glacial aquifer was also estimated from specific-capacity data. Bredehoeft (1963) presents a method for calculating hydraulic conductivity from specific-capacity data and discusses the sensitivity of the calculations to changes in the value of various other aquifer properties. The study at East Meadow used a modified version of Bredehoeft's method, described in McClymonds and Franke (1972). The equation used is:

$$
K=114.6 \mathrm{~W}(u) \frac{\mathrm{Q}}{\mathrm{sL}}
$$


where: $\mathrm{K}=$ average hydraulic conductivity of the material surrounding the well screen, in (gal/d)/ft ${ }^{2}$;

$Q=$ discharge of the pumping well, in gal/min;

$s=d r a w d o w n$ of the pumping well, in $f t ;$

$\mathrm{L}=$ length of the well screen, in $\mathrm{ft}$;

$W(u)=$ well function

$$
\text { where: } \begin{aligned}
\mathrm{u}= & 1.87 \mathrm{r}^{2} \frac{\mathrm{S}}{\mathrm{Tt}}, \\
\mathrm{r}= & \text { distance to point of observation (in this case, well radius), } \\
& \text { in ft; } \\
\mathrm{S}= & \text { storage coefficient (dimensionless); } \\
\mathrm{T} & =\text { transmissivity, in (gal/d)/ft; and } \\
\mathrm{t} & =\text { time since pumping began, in days. }
\end{aligned}
$$

Calculation of hydraulic conductivity requires initial estimates of storage coefficient and transmissivity; therefore, an iterative method of refining these values is necessary.

Implicit in using this equation to estimate hydraulic conductivity is the assumption that all water is supplied to the well along horizontal flow lines from the aquifer material surrounding the well screen. In reality, some water flows to the well from both above and below the screen, especially if a gravel pack surrounds the screen zone. (Gravel-packing the screen zone also increases the effective radius of the well screen, causing error in the value of $r_{.}$)

Calculating hydraulic conductivity from specific-capacity data by equation 3 requires an estimate of the storage characteristics of the aquifer. If the aquifer is unconfined (water-table conditions), the specific yield might range from 0.10 to 0.40 , and the calculated hydraulic conductivity would be relatively insensitive to variations in specific yield over this range. If the aquifer is partly confined, however, the storage-coefficient values could be in error by several orders of magnitude.

Hydraulic conductivity of the Magothy aquifer was not estimated by this method because the screened interval of the production well also taps the upper glacial aquifer; thus, any estimate of hydraulic conductivity based on specific capacity of the well would be some composite value of both aquifers.

Radial hydraulic conductivity of the upper glacial aquifer, calculated from an assumed specific yield of 0.15 and a specific capacity for the production well of $34.5(\mathrm{gal} / \mathrm{min}) / \mathrm{ft}$ of $\mathrm{drawdown}$, was $450 \mathrm{ft} / \mathrm{d}$, reasonably close to the $510 \mathrm{ft} / \mathrm{d}$ obtained by the Thiem equation.

\section{Neuman's Delayed Yield Method for Hydraulic Conductivity, Storage Coefficient, and Specific Yield}

Hydraulic conductivity and storage properties of the upper glacial aquifer were also estimated with an analytical method developed by Neuman (1975) that accounts for delayed gravity drainage in an unconfined aquifer being pumped by a partially penetrating production well. Typically, 

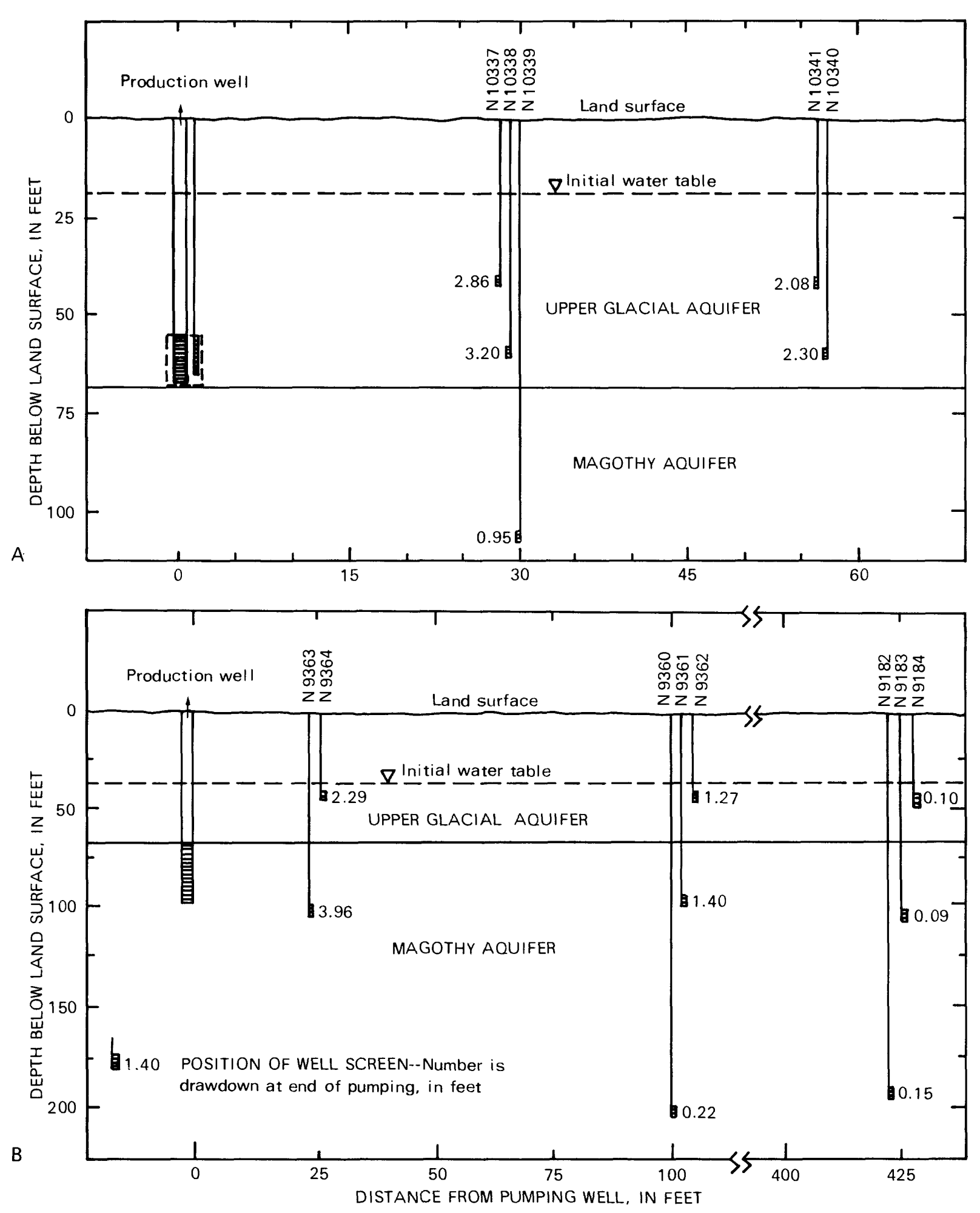

Figure 8.--Vertical section of aquifer showing drawdown in each well at end of pumping period: A. Upper glacial aquifer test. $B$. Magothy aquifer test. 
time-vs-drawdown curves for unconfined aquifers with delayed yield generally show three distinct segments, as illustrated by the lower curve in figure 9 The first segment, which shows a rapid increase, reflects the release of water from storage as a result of aquifer compaction and expansion of the water, similar to the response of a confined aquifer (the Theis curve). The second segment, characterized by a distinct flattening, reflects an intermediate stage, where drawdown is attenuated as water is released from storage through gravity drainage at the water table, and the response reflects some combination of confined and unconfined conditions. The third segment, which shows an increase, reflects the expansion of the cone of depression. At this stage, the aquifer response conforms closely to the Theis nonequilibrium type curve.

Neuman's analytical method accounts for the delayed gravity drainage by treating the unconfined aquifer as a compressible system and the water-table surface as a moving streamline boundary. The method also takes into account aquifer anisotropy and the effects of partial penetration of both the production and observation wells. A detailed explanation of Neuman's method is beyond the scope of this report, but the theory of delayed yield and the application of the analytical model is outlined in several articles by Neuman $(1972,1974,1975)$.

Simply stated, the analytical model expresses the final solution in terms of six dimensionless terms: $\sigma, \beta, \mathrm{z}_{\mathrm{D}}, l_{\mathrm{d}}, \mathrm{d}_{\mathrm{p}}$, and $t_{s}$ or $t_{\mathrm{y}}$

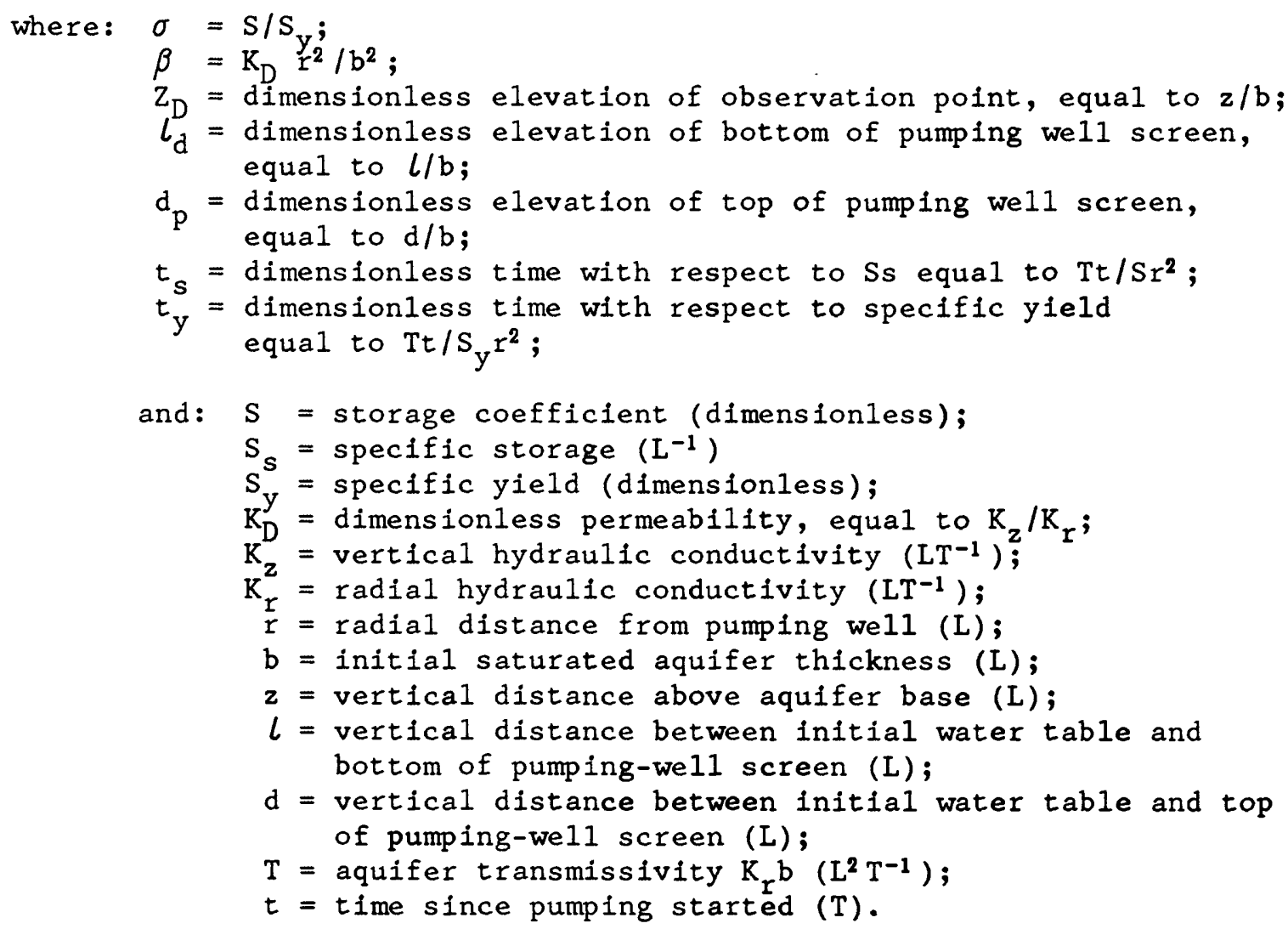

The analytical solution will yield a dimensionless drawdown at a dimensionless time from the values of the six dimensionless terms listed above. 


\section{Figure 9.}

Generalized diagram showing drawdown through time in a pumping well screened in a confined aquifer and $a$ watertable aquifer with delayed gravity drainage.

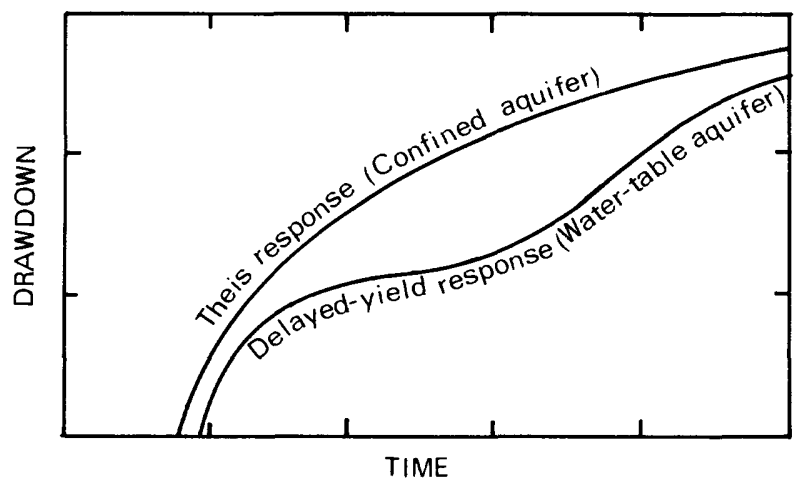

The aquifer-test data were analyzed through Neuman's (1975) analytical solution to calculate the dimensionless drawdown at an observation well for several different times. These values of dimensionless time and drawdown were converted to dimensional drawdown and time and plotted for comparison with observed well-drawdown curves. The values of selected aquifer properties were varied through a trial-and-error technique until the best simultaneous match between observed and calculated drawdowns through time was obtained in wells $\mathrm{N} 10337$, N10338, N10340, and N10341, all screened in the upper glacial aquifer (locations shown in fig. 7). Computed and observed drawdowns in the four wells are plotted in figure 10 .

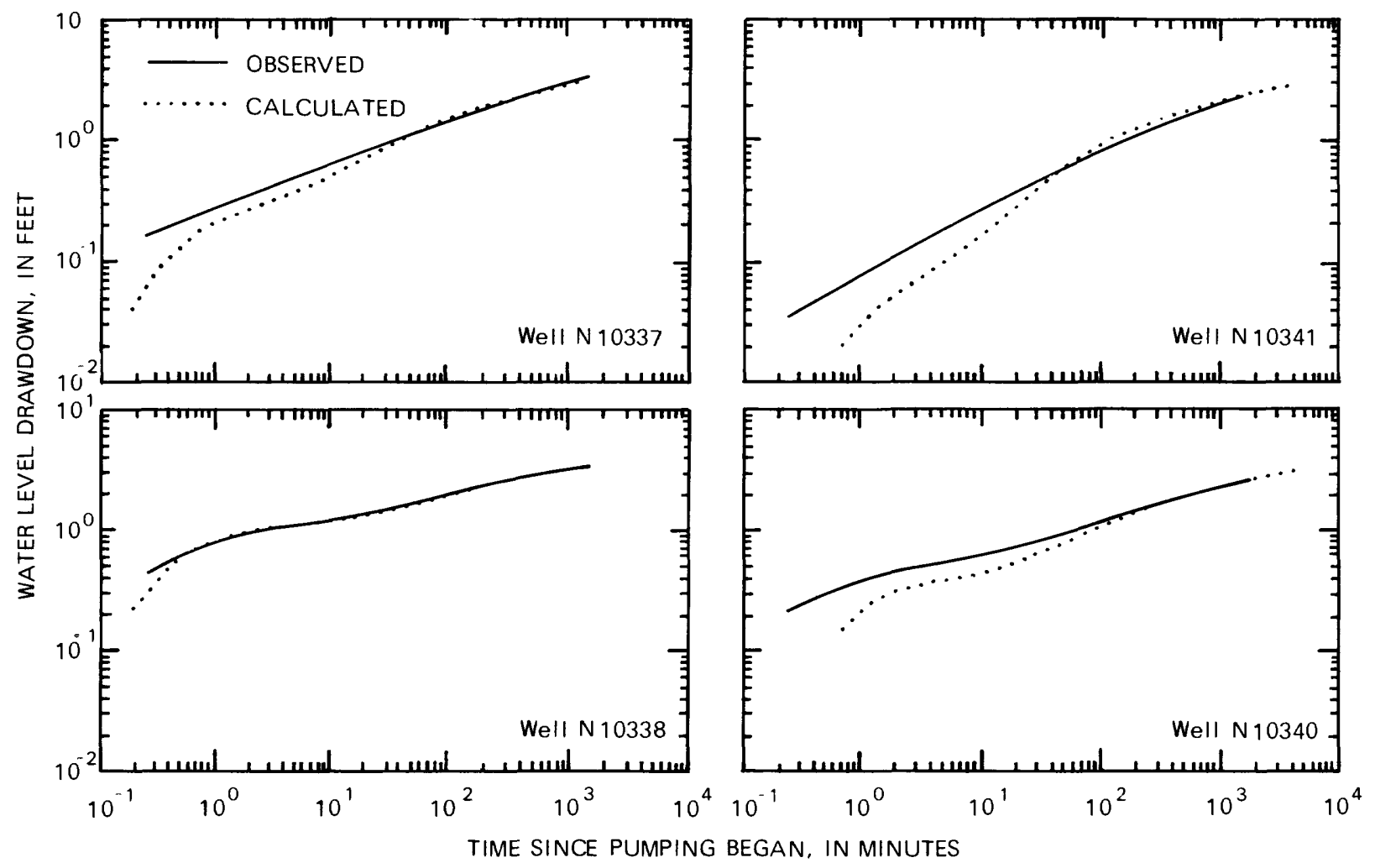

Figure 10.--Comparison of observed drawdown at four wells screened in the upper glacial aquifer with those computed through Neuman's (1975) delayed-yield method. 
Values for hydraulic characteristics calculated by the delayed-yield analytical solution were in a range similar to those obtained from the simple analytical solutions. Radial hydraulic conductivity of the upper glacial aquifer was estimated to be $450 \mathrm{ft} / \mathrm{d}$, with a ratio of horizontal to vertical hydraulic conductivity of 3.8. Specific (elastic) storage of the upper glacial aquifer was estimated to be $2.3 \times 10^{-4} \mathrm{ft}^{-1}$, and specific yield was 0.12 .

\section{Type-Curve Analysis}

Two methods of curve matching were used to evaluate the aquifer test data--a method developed by R. W. Stallman (in Lohman, 1972) and a method derived by Boulton (1963) that empirically accounts for delayed yield from storage. The upper glacial aquifer test was designed to closely duplicate the electric-analog radial-flow model originally used by Stallman to generate the dimensionless time-vs-drawdown type curves. Because the well configuration in the Magothy aquifer test did not correspond to the design or assumptions of any of the available curve-matching techniques, the time-vs-drawdown curves from the Magothy aquifer test are unique and cannot be fitted to any available type curve. Therefore, the following discussion of the analysis based on dimensionless time-vs-drawdown curves concerns only the upper glacial aquifer test.

\section{Stallman Method for Calculating Hydraulic Conductivity and Specific Yield}

Stallman developed dimensionless time-vs-drawdown curves for five different penetrations of observation wells $(0,50,75,90$, and 100 percent of the aquifer's saturated thickness, "b") with a production well having a radius of $0.002 \mathrm{~b}$ and screened at the bottom third of the aquifer. Assumed in this method is that the aquifer is anisotropic, radially symmetric, and homogeneous. By considering vertical flow in the aquifer, Stallman generated dimensionless plots for different ratios of radial and vertical hydraulic conductivity, $\mathrm{K}_{\mathrm{r}} / \mathrm{K}_{\mathrm{z}}$.

In the East Meadow study, drawdowns at the five wells screened in the upper glacial aquifer were plotted against time on log-log paper and fitted to the appropriate family of type curves according to observation-well penetration. An exact match of the observed data with the theoretical type curves was impossible because the curves have the same general shape, which makes the interpretation subjective. Wherever possible, several different curve matches were selected to provide a range in values of aquifer properties. Specific yield was more sensitive than aquifer transmissivity to various fits of data to the type curve and often ranged over nearly an order of magnitude.

The lowest specific-yield estimates obtained from the analyses were those for the deeper wells, N10338, N10340, and N10342. (Locations are shown in fig. 7.) This is probably the result of the good hydraulic connection with the underlying Magothy aquifer, where the contribution of water from the deeper aquifer has undoubtedly altered the relationship between time and drawdown. This is also probably the main reason why the hydraulic conductivity estimates were higher than expected--a saturated thickness of $29 \mathrm{ft}$ was 
assumed for the upper glacial aquifer in this analysis, but the contribution of the Magothy aquifer to the production well increases the functional aquifer thickness somewhat, which would give higher hydraulic conductivity values than expected.

The original electric-analog model used by Stallman to generate the dimensionless time-vs-drawdown curves ignored changes in saturated thickness; therefore such changes are a source of error in the analysis. Maximum drawdowns in the observation wells screened at the water table were relatively sma11, less than 10 percent of the saturated thickness. Drawdowns near the pumping well were somewhat greater, though, nearly $15 \mathrm{ft}$ ( 49 percent) in the annular well screened in the gravel pack of the production well. Water-level drawdown at the free surface near the production well was no doubt considerably less than that in the annular well, however, because the production well tapped the bottom of the aquifer and was thus partially penetrating. The actual free-surface drawdown near the production well was probably no more than $4 \mathrm{ft}$.

Table 9.--Results from Stallman type-curve analysis for the upper glacial aquifer test.

[We11 locations are shown in fig. 7.]

\begin{tabular}{|c|c|c|c|c|}
\hline $\begin{array}{c}\text { Well } \\
\text { no. }\end{array}$ & $\begin{array}{c}\text { Transmissivity } \\
\left(\mathrm{ft}^{2} / \mathrm{d}\right)\end{array}$ & $\begin{array}{c}\text { Average } \\
\text { horizontal } \\
\text { hydraulic } \\
\text { conductivity } \\
(\mathrm{ft} / \mathrm{d})\end{array}$ & $\begin{array}{c}\text { Ratio of } \\
\text { horizontal to } \\
\text { vertical } \\
\text { hydraulic } \\
\text { conductivity } \\
\left(\mathrm{K}_{\mathrm{r}} / \mathrm{K}_{z}\right) \\
\text { (dimensionless) }\end{array}$ & $\begin{array}{l}\text { Specific yield } \\
\text { (dimensionless) }\end{array}$ \\
\hline N10337 & $\begin{array}{l}15,800 \\
14,000 \\
15,400\end{array}$ & $\begin{array}{l}540 \\
480 \\
530\end{array}$ & $\begin{array}{l}2.2 \\
2.9 \\
1.4\end{array}$ & $\begin{array}{r}0.05 \\
.18 \\
.17\end{array}$ \\
\hline N10338 & $\begin{array}{l}16,000 \\
16,000 \\
18,800\end{array}$ & $\begin{array}{l}550 \\
550 \\
650\end{array}$ & $\begin{array}{l}2.9 \\
1.4 \\
1.4\end{array}$ & $\begin{array}{l}.10 \\
.04 \\
.03\end{array}$ \\
\hline N10340 & $\begin{array}{l}18,500 \\
17,800 \\
18,100\end{array}$ & $\begin{array}{l}640 \\
615 \\
625\end{array}$ & $\begin{array}{l}4.3 \\
4.3 \\
1.4\end{array}$ & $\begin{array}{l}.07 \\
.06 \\
.06\end{array}$ \\
\hline N10341 & $\begin{array}{l}15,800 \\
16,000 \\
16,000\end{array}$ & $\begin{array}{l}545 \\
550 \\
550\end{array}$ & $\begin{array}{l}4.3 \\
6.5 \\
1.4\end{array}$ & $\begin{array}{l}.13 \\
.14 \\
.14\end{array}$ \\
\hline N10342 & $\begin{array}{l}16,000 \\
16,300 \\
14,500\end{array}$ & $\begin{array}{l}550 \\
560 \\
500\end{array}$ & $\begin{array}{l}4.3 \\
1.4 \\
1.4\end{array}$ & $\begin{array}{l}.05 \\
.02 \\
.03\end{array}$ \\
\hline $\begin{array}{l}\text { Range of } \\
\text { values }\end{array}$ & $14,000-18,800$ & $480-650$ & $1.4-6.5$ & $.02-.18$ \\
\hline Mean value & 16,333 & 562 & 2.8 & .08 \\
\hline $\begin{array}{l}\text { Standard } \\
\text { deviation }\end{array}$ & 1,385 & 49 & 1.6 & .05 \\
\hline
\end{tabular}


Results of the Stallman type-curve analysis are summarized in table 3 . Radial hydraulic conductivity values ranged from 480 to $650 \mathrm{ft} / \mathrm{d}$, with an average of $562 \mathrm{ft} / \mathrm{d}$. Although this range is fairly narrow, the values are greater than the 270 to $335 \mathrm{ft} / \mathrm{d}$ reported by McClymonds and Franke (1972) for the upper glacial aquifer in central Nassau County. Values for specific yield were 0.02 to 0.18 , the first of which is much lower than would be expected for an unconfined aquifer. Specific yield in unconfined sand and gravel aquifers such as the upper glacial aquifer generally ranges from 0.16 to 0.28 (Todd, 1980). Specific-yield estimates for the two shallow wells were between 0.13 to 0.18 , and most were within the range reported in the literature.

\section{Boulton's Delayed-Yield Method for Calculating Hydraulic Conductivity, Storage Coefficient, and Specific Yield}

The second curve-matching technique was one developed by Boulton (1963), which considers the phenomenon of delayed yield from aquifer storage.

Boulton's type curves are based on a semiempirical mathematical relationship that assumes all water released from storage to be the sum of two components--S $S_{e}$ a volume of water released instantaneously at time $t$ (early time storage coefficient), and $S_{l}$, a volume whose release is delayed (later time specific yield). This family of type curves was developed from a radial-flow equation in which the effects of vertical gradients and anisotropy are combined into an empirical constant. Although the method is not based on a rigorous mathematical approximation of the physical system, the analysis is quick and may help identify the compressive storage characteristics of the upper glacial aquifer.

The time-vs-drawdown plots from the five wells screened in the upper glacial aquifer were fit to the delayed-yield type curves. The curve-fitting procedure for the delayed-yield type curves is similar to the Stallman curve-fitting technique except that two matches can generally be made; one at early times to provide an estimate of the aquifer's compressive storage characteristics $\left(S_{e}\right)$, and one at late times to provide an estimate of specific yield $\left(S_{l}\right)$. Again, an exact match of the observed data with the type curves was impossible; therefore, several different matches were selected to provide a range in aquifer-property values. Both an early $\left(S_{e}\right)$ and a late $\left(S_{l}\right)$ match with the theoretical type curve were made, but aquifer-transmissivity values for most of the early matches were unreasonably high. For this reason, only the transmissivity values from the late curve match are listed in the summary of results from this analysis (table 4). Values of early storage should be used with caution because they are calculated from transmissivity values obtained from the early curve match.

The range of hydraulic-property values obtained through the delayedyield type-curve technique was similar to that obtained through the Stallman type curves and Neuman's (1975) analytical solution for delayed yield. Radial hydraulic conductivity values were between 455 and $615 \mathrm{ft} / \mathrm{d}$, with an average of $523 \mathrm{ft} / \mathrm{d}$. Late storage values $\left(\mathrm{S}_{l}\right)$ were between 0.03 and 0.17 , close to the values obtained from the Stallman type curves, and early storage values $\left(S_{e}\right)$ were between 0.0008 and 0.01 . Curves from the deeper wells screened in the upper glacial aquifer gave low estimates of specific yield, similar to those obtained from the Stallman method; again, this was attributed to the 
hydrologic influence of the underlying and hydraulically connected Magothy aquifer.

Table 4.--Results of Boulton delayed-yield type-curve solution for upper glacial aquifer test.

[We11 locations are shown in fig. 7, dash indicates unreasonable value calculated.]

\begin{tabular}{|c|c|c|c|c|}
\hline $\begin{array}{c}\text { We11 } \\
\text { no. }\end{array}$ & $\begin{array}{c}\text { Transmissivity } \\
\left(f t^{2} / d\right)\end{array}$ & $\begin{array}{c}\text { Average } \\
\text { horizontal } \\
\text { hydraulic } \\
\text { conductivity } \\
\text { (ft/d) }\end{array}$ & $\begin{array}{c}\mathrm{S}_{\mathrm{e}} \\
\text { (dimensionless) }\end{array}$ & $\begin{array}{c}s_{l} \\
\text { (dimensionless) }\end{array}$ \\
\hline N10337 & $\begin{array}{l}13,400 \\
14,200 \\
15,300\end{array}$ & $\begin{array}{l}460 \\
490 \\
530\end{array}$ & $\begin{array}{c}-- \\
0.0008 \\
.008\end{array}$ & $\begin{array}{r}0.17 \\
.17 \\
.15\end{array}$ \\
\hline N10338 & $\begin{array}{l}14,200 \\
17,800 \\
13,200\end{array}$ & $\begin{array}{l}490 \\
615 \\
455\end{array}$ & $\begin{array}{l}.003 \\
.003 \\
.004\end{array}$ & $\begin{array}{l}.06 \\
.03 \\
.07\end{array}$ \\
\hline N10340 & $\begin{array}{l}15,000 \\
17,000 \\
16,300\end{array}$ & $\begin{array}{l}515 \\
585 \\
560\end{array}$ & $\begin{array}{l}.002 \\
.002 \\
.003\end{array}$ & $\begin{array}{l}.10 \\
.05 \\
.06\end{array}$ \\
\hline N10341 & $\begin{array}{l}13,900 \\
15,900 \\
16,300\end{array}$ & $\begin{array}{l}480 \\
550 \\
560\end{array}$ & $\begin{array}{l}.- \\
.01 \\
.-\end{array}$ & $\begin{array}{l}.12 \\
.13 \\
.12\end{array}$ \\
\hline N10342 & $\begin{array}{l}13,400 \\
17,400 \\
14,500\end{array}$ & $\begin{array}{l}460 \\
600 \\
500\end{array}$ & $\begin{array}{l}.006 \\
.003 \\
.006\end{array}$ & $\begin{array}{l}.04 \\
.08 \\
.03\end{array}$ \\
\hline $\begin{array}{l}\text { Range of } \\
\text { values }\end{array}$ & $13,200-17,800$ & $455-615$ & $.0008-.01$ & $.03-.17$ \\
\hline Mean & 15,188 & 523 & .004 & .09 \\
\hline $\begin{array}{l}\text { Standard } \\
\text { deviation }\end{array}$ & 1,525 & 52 & .003 & .05 \\
\hline
\end{tabular}

\section{Numerical-Model Analysis}

Both aquifer-test designs used in this study violate some of the basic simplifying assumptions necessary for proper use of the analytical methods and curve-matching techniques described in the preceding section. Use of a numerical model enables a more accurate simulation of the actual field conditions of both tests. The numerical model can simulate the water-level response in observation wells regardless of their location in the aquifer and also can simulate an aquifer test involving a production well that taps more than one aquifer or where more than one aquifer is present. Furthermore, numerical-model analysis is not limited to the pumping part of the well response, where variations in pumping rate can have adverse effects on data analysis; it can simulate both the pumping and recovery cycles of the test. 
Also, local variations in the geologic environment can be incorporated to provide estimates of hydrologic characteristics of the individual units.

Numerical-model analysis of each aquifer test provided much more reliable estimates of horizontal and vertical hydraulic conductivity and aquifer storativity (storage coefficient and specific yield) of both the Magothy and upper glacial aquifers than is possible from analytical methods or curve-matching techniques alone.

\section{Methods and Assumptions}

A transient-state Galerkin finite-element flow model developed by Reilly (1984) was used to simulate the drawdown and recovery curves obtained from the two aquifer tests. The model simulates ground-water flow through a representative vertical cross section of aquifer that is radially symmetric around the axis of the production well. The model can simulate hydraulic response to pumping in an aquifer that is not homogeneous, regardless of well-screen penetration, provided that the aquifer is radially symmetric. Horizontal $\left(K_{r}\right)$ and vertical $\left(\mathrm{K}_{2}\right)$ hydraulic conductivity can vary locally within the model although they are constant within a single model element. This enables the user to accurately model all major aquifers and confining units. Some of the assumptions and restrictions inherent in the model are that:

- Specific yield $\left(\mathrm{S}_{\mathrm{y}}\right)$ is constant along the free surface;

- the well has no seepage face;

- the aquifer is of finite extent; and

- the pumping rate is constant.

Two modifications were made to the model code to better approximate the field conditions at the aquifer-test site. The first was made by Reilly (U.S. Geological Survey, written commun., 1986) to allow for decreases in saturated thickness of the upper glacial aquifer as the water table is drawn down in response to pumping. This is done through an iterative technique in which the program checks for drawdown at the top layer of nodes at the end of each time step, and node locations in the finite-element grid are altered vertically to account for the new location of the free surface. The program then iterates through the solution until head changes at the free surface between successive iterations are less than a prescribed value. The second modification, by the authors, enabled the use of variable specific storage $\left(S_{s}\right)$ throughout the model to more accurately simulate the storage characteristics of the upper glacial ( $S_{y}$ and $S_{s}$ ) and Magothy aquifers $\left(S_{s}\right)$.

\section{Procedures}

Each pumping test was simulated on a unique grid that was generated by a mesh-generating computer program. The mesh-generating program allows the user to specify the location of individual nodes, which results in a regularly shaped grid (uniform layering with radial distance from the well), as shown in figures 11 and 12. Although this results in a somewhat less efficient use of computation time and computer storage, the benefits in initial grid-setup time over a manually generated grid far outweigh the disadvantages. Furthermore, grid-design and setup time were so rapid that it was possible to design an individual grid that specifically met the needs of each aquifer test. 
The model was used to refine hydraulic values of each aquifer on a trialand-error basis. Initial estimates of the aquifer properties were based on the analytical solutions, type-curve analyses, and published estimates of aquifer properties in the East Meadow area (Aronson and others, 1983). No information on the compressive storage of the upper glacial aquifer was available; therefore, a dimensionless value of $5.0 \times 10^{-7}$ (the compressibility of pure water) was used for the storage coefficient of the aquifer. Simulated drawdown and recovery curves were compared with observed drawdown and recovery curves for each observation well, and the resultant matches were evaluated. Sensitivity tests were run on selected variables to reveal which affected the drawdown and recovery curves most severely; these are the aquifer characteristics that may be adjusted in the model to best approximate the observed responses.

Simulation of Magothy aquifer test.--The Magothy aquifer test was simulated on a grid with 990 nodes and 1,856 elements, as shown in figure 11. The area simulated extends from the radius of the pumping well $(0.5 \mathrm{ft})$ to an artificial no-flow boundary $21,000 \mathrm{ft}$ from the well axis, where no measurable drawdown was expected to occur during the test. Two major hydrologic units were simulated--489 ft of Magothy aquifer from the top of the clay member of the Raritan Formation to the base of the upper glacial aquifer, and $33 \mathrm{ft}$ of saturated deposits of the upper glacial aquifer. The Raritan clay was assumed to yield no water to the production well or the Magothy aquifer during the test and was therefore modeled as an impermeable boundary. The aquifers were simulated as radially symmetric, horizontal, homogeneous layers of uniform thickness. Both aquifers contain thin silt and clay lenses but were excluded from the model because neither the water-transmitting properties of these layers nor their areal extent were known. The hydraulic-conductivity values that result from omission of the thin silt and clay lenses will be some composite of both the high-and low-permeability zones. This, in effect, yields average local values of hydraulic conductivity for the entire aquifer.
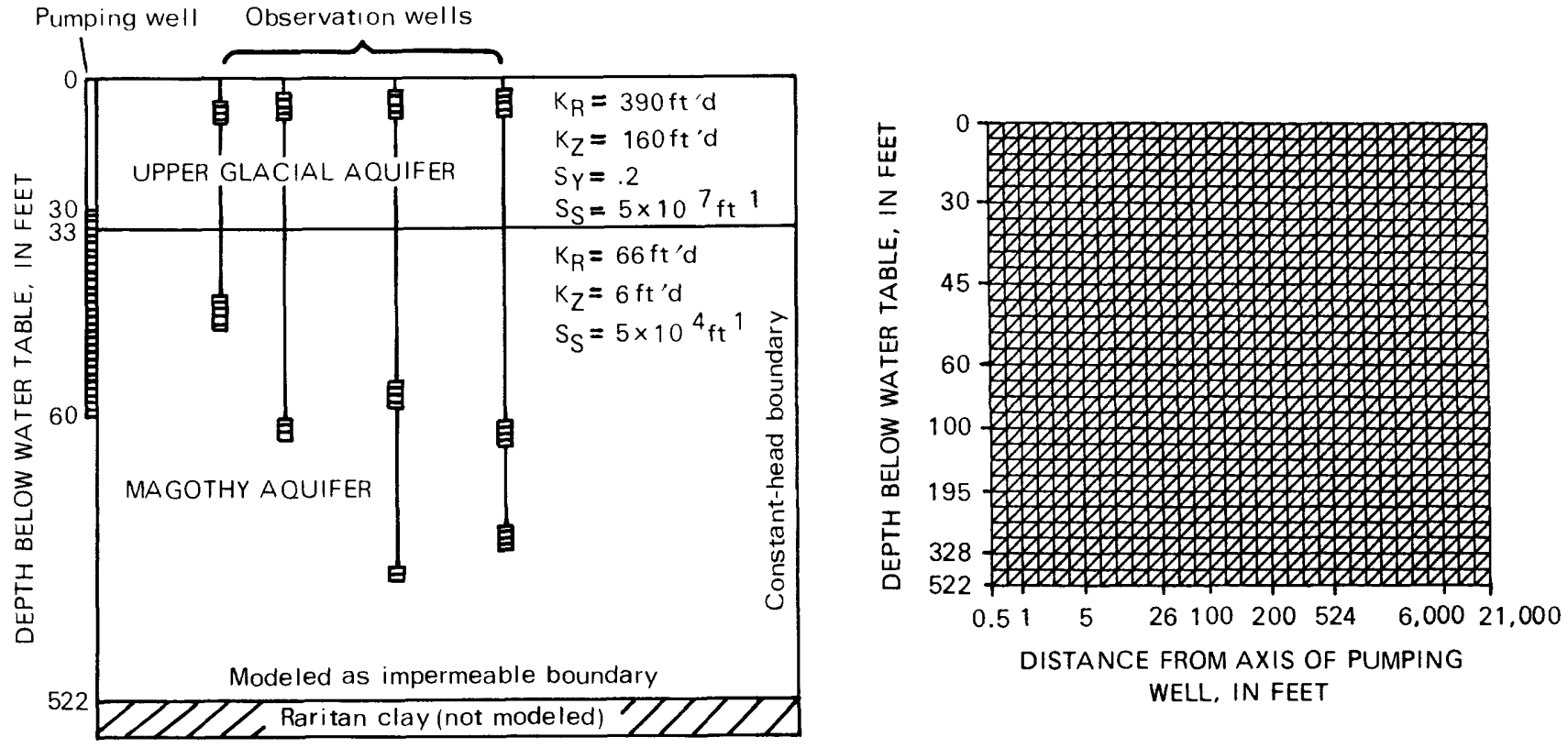

Figure 11.--Vertical section of Magothy aquifer test site: Main components and initial values for aquifer properties (left), and finiteelement grid used over same area (right). 
The Magothy aquifer-test design is depicted in figure 11, which shows the thickness of the upper glacial and Magothy aquifers, observation-well locations, production-well screen zone, and the aquifer properties specified in the initial model run. In addition to the aquifer characteristics shown, a gravel pack having a radius of $1 \mathrm{ft}$ and a horizontal and vertical hydraulic conductivity of $100,000 \mathrm{ft} / \mathrm{d}$ was simulated around the screen of the production well.

Inspection of the various sensitivity plots revealed which aquifer values needed adjustment to approximate the observed water-level response curves. The sensitivity analysis also revealed that the drawdown and recovery predicted by the model were relatively insensitive to vertical hydraulic conductivity and specific storage of the upper glacial aquifer and to hydraulic conductivity of the production well's gravel pack. The water-level response was highly sensitive to the ratio of the horizontal to vertical hydraulic conductivity of the gravel pack, though, undoubtedly because this affects the degree to which the well screen can communicate stress to the upper glacial aquifer.

The relative insensitivity of the simulated drawdowns to variations of some of the aquifer characteristics, such as vertical hydraulic conductivity and specific storage of the upper glacial aquifer, indicates that the values obtained in this analysis are not unique and may be in error. Furthermore, the simulated water-level response was only moderately sensitive to variations in horizontal hydraulic conductivity and specific yield of the upper glacial aquifer; thus, these values can be considered to be only approximate.

Simulation of upper glacial aquifer test.--The upper glacial aquifer test was simulated on a grid with 1,050 nodes and 1,972 elements with the dimensions shown in figure 12. The area simulated extended from the radius of the pumping well ( $0.33 \mathrm{ft})$ to an artificial no-flow boundary 21,000 ft from the well axis, where no measurable drawdown was expected during the test.

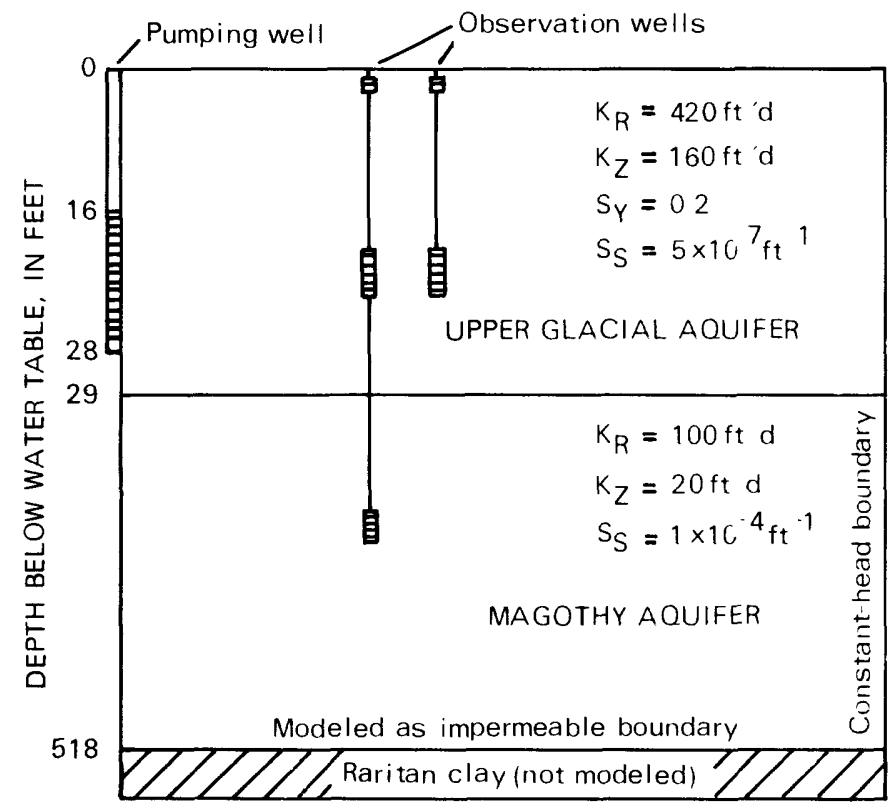

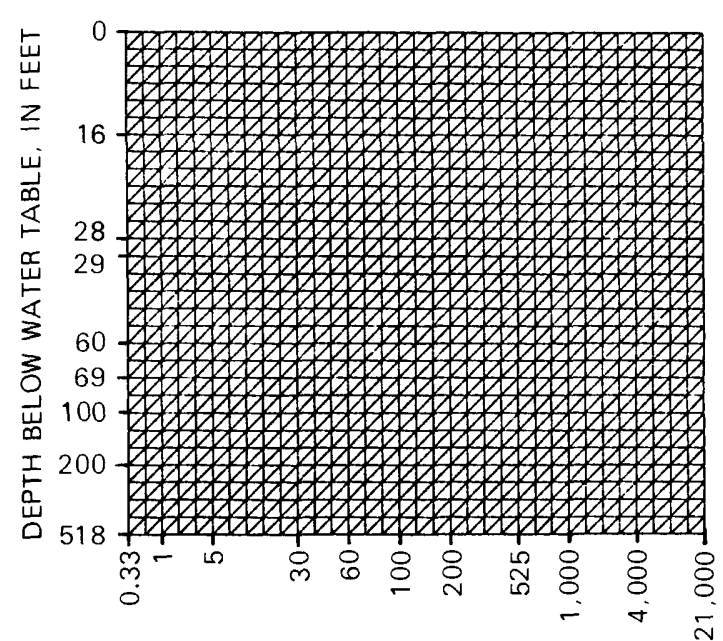

DISTANCE FROM AXIS OF PUMPING WELL, IN FEET

Figure 12.--Vertical section of upper glacial aquifer test site: Main components and initial values for aquifer properties (left) and finite-element grid over same area (right). 
As in the simulation of the Magothy aquifer test, two major hydrologic units were simulated--489 ft of Magothy aquifer from the top of the Raritan clay to the base of the upper glacial aquifer, and $29 \mathrm{ft}$ of saturated upper glacial deposits. Again, the Raritan clay was modeled as a no-flow boundary. The aquifers were simulated as being radially symmetric, horizontal, homogeneous layers of uniform thickness. Again, the numerous thin silt and clay lenses were not simulated.

The design of the upper glacial aquifer test is depicted in figure 12 to show the thickness of the aquifers, observation-well locations, productionwell-screen zones, and the initial aquifer-property values. The production well was simulated as having a gravel pack with a radius of $1 \mathrm{ft}$ along the length of the screen and a 1-ft-thick bentonite plug at its base. The hydraulic conductivity of the gravel pack was $100,000 \mathrm{ft} / \mathrm{d}$ both horizontally and vertically; that of the bentonite plug was $1 \mathrm{ft} / \mathrm{d}$ horizontally and vertically.

Sensitivity analysis of the upper glacial aquifer test showed the water-level response to be relatively insensitive to vertical and horizontal hydraulic conductivity of the Magothy aquifer and to specific storage of the upper glacial aquifer. Again, this suggests that the values used for these aquifer characteristics may be in error.

\section{Results of Numerical-Model Analysis}

The Magothy aquifer-test analysis gave horizontal hydraulic conductivity values of $100 \mathrm{ft} / \mathrm{d}$ for the Magothy aquifer and $420 \mathrm{ft} / \mathrm{d}$ for the upper glacial aquifer. The ratio of horizontal to vertical hydraulic conductivity was 5.0 for the Magothy and 2.1 for the upper glacial aquifers. Specific yleld of the upper glacial aquifer was 0.20. Specific storage for the upper glacial aquifer was $1.0 \times 10^{-6} \mathrm{ft}^{-1}$ and that for the Magothy aquifer was $1.0 \times 10^{-4}$ $\mathrm{ft}^{-1}$. Simulated and observed drawdowns and recoveries for the Magothy aquifer test are plotted in figure 13; final values from both test simulations are listed in table 5.

The upper glacial aquifer test analysis gave horizontal hydraulic conductivity values of $125 \mathrm{ft} / \mathrm{d}$ for the Magothy aquifer and $380 \mathrm{ft} / \mathrm{d}$ for the upper glacial aquifer. The ratio of horizontal to vertical hydraulic conductivity was 8.3 for the Magothy and 2.5 for the upper glacial aquifers. Specific yield of the upper glacial aquifer was 0.15 . Specific storage for the upper glacial aquifer was $1.0 \times 10^{-4} \mathrm{ft}^{-1}$, and that for the Magothy aquifer was $5.0 \times 10^{-6} \mathrm{ft}^{-1}$. The simulated and observed drawdowns and recoveries for the upper glacial aquifer test are plotted in figure 14.

Errors in the numerical-model analysis may arise from three major sources--(1) unavoidable variations in the pumping rate during the test, (2) lack of radial symmetry in the aquifer system, and (3) nonuniqueness of the solution. The effects of these are described below.

(1) The unavoidable variations in pumping rates during the test would give inconsistent results. (The average pumping rate should equal the value used in the simulations to minimize the error these fluctuations may cause.) 
(2) The lack of radial symmetry at each aquifer-test site contributes an unknown error. Because the observation wells in the Magothy aquifer test were arranged in a straight north-south-trending line (fig. 6), the effects of radial asymmetry could not be seen, and radial symmetry is merely assumed. In contrast, the upper glacial aquifer test was designed so that radial symmetry could be verified from the response of wells $\mathrm{N} 10338$ and $\mathrm{N} 10342$, which are radially equidistant from the production well but at right angles to each other and screened at the same horizon (fig. 7). The observed-drawdown curves for these two wells differ slightly in both magnitude and shape (fig. 14, solid line), which indicates some degree of radial asymmetry. An assessment of the effects of this asymmetry was beyond the scope of the study, however.

(3) One aspect of the solution's nonuniqueness is the insensitivity of model drawdowns and recovery to variations in the value of several aquifer characteristics. In the Magothy aquifer-test simulation, these were vertical hydraulic conductivity and specific storage of the upper glacial aquifer; in the upper glacial aquifer-test simulation, they were the horizontal and vertical hydraulic conductivity of the Magothy aquifer and specific storage of the upper glacial aquifer. The insensitivity of the predicted heads to the value of these terms indicates that the estimated

Table 5.--Final values used in numerical simulation of Magothy and upper glacial aquifer tests.

\begin{tabular}{lcc}
\hline \multicolumn{1}{c}{$\begin{array}{c}\text { Aquifer } \\
\text { characteristic }\end{array}$} & $\begin{array}{c}\text { Magothy aquifer } \\
\text { test }\end{array}$ & $\begin{array}{c}\text { Upper glacial aquifer } \\
\text { test }\end{array}$ \\
\hline $\begin{array}{l}\text { MAGOTHY AQUIFER } \\
\text { Horizontal hydraulic } \\
\text { conductivity (ft/d) }\end{array}$ & 100 & $\star 125$ \\
$\begin{array}{l}\text { Vertical hydraulic } \\
\text { conductivity (ft/d) }\end{array}$ & 20 & $\star 15$ \\
$\begin{array}{l}\text { Coefficient of specific } \\
\text { storage (ft-1) }\end{array}$ & $1.0 \times 10^{-4}$ & $5.0 \times 10^{-6}$ \\
$\begin{array}{l}\text { Horizontal hydraulic } \\
\text { conductivity (ft/d) }\end{array}$ & 420 & 380 \\
$\begin{array}{l}\text { Vertical hydraulic } \\
\text { conductivity (ft/d) }\end{array}$ & $\star 200$ & 150 \\
$\begin{array}{l}\text { Specific storage (ft-1) } \\
\begin{array}{l}\text { Specific yleld } \\
\text { (dimensionless) }\end{array}\end{array}$ & $\star 1.0 \times 10^{-8}$ & $\star 1.0 \times 10^{-4}$ \\
\hline
\end{tabular}

* Model results were not sensitive to changes in this parameter; therefore, values may not be reliable. 
values for these terms may be in error. The simulated drawdowns and recoveries in both tests were insensitive to variation in the specific storage of the upper glacial aquifer. Changes in all other terms significantly affected the
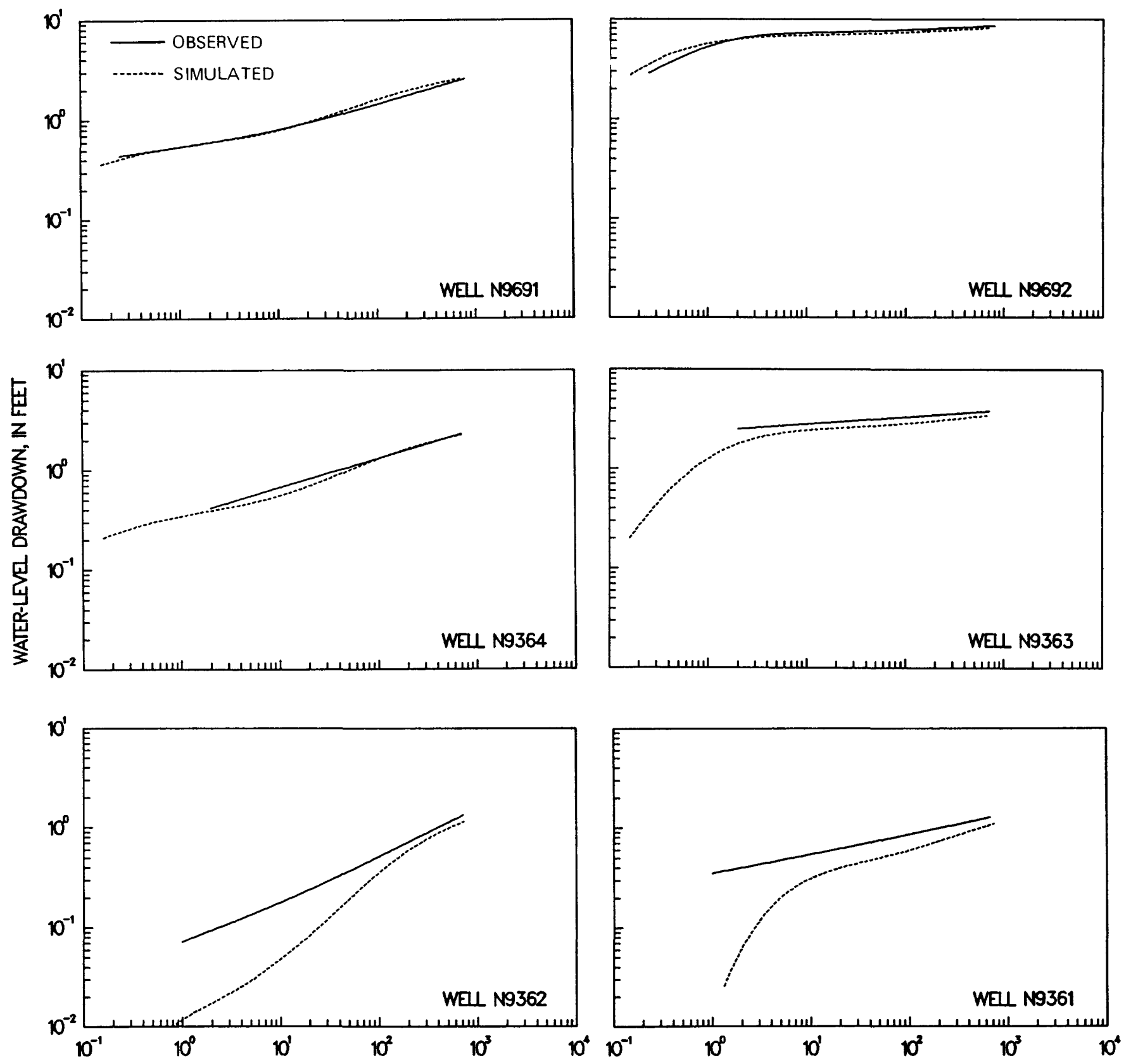

TIME SINCE PUMPNG BEGAN, N MNUTES

Figure 13A.--Comparison of observed with simulated drawdowns at observation wells in the Magothy aquifer test. (Well locations are shown in fig. 6.) 
water-level response in at least one of the aquifer tests. Therefore, the combination of the two analyses yields fairly reliable values for all aquifer properties other than the specific storage of the upper glacial aquifer.
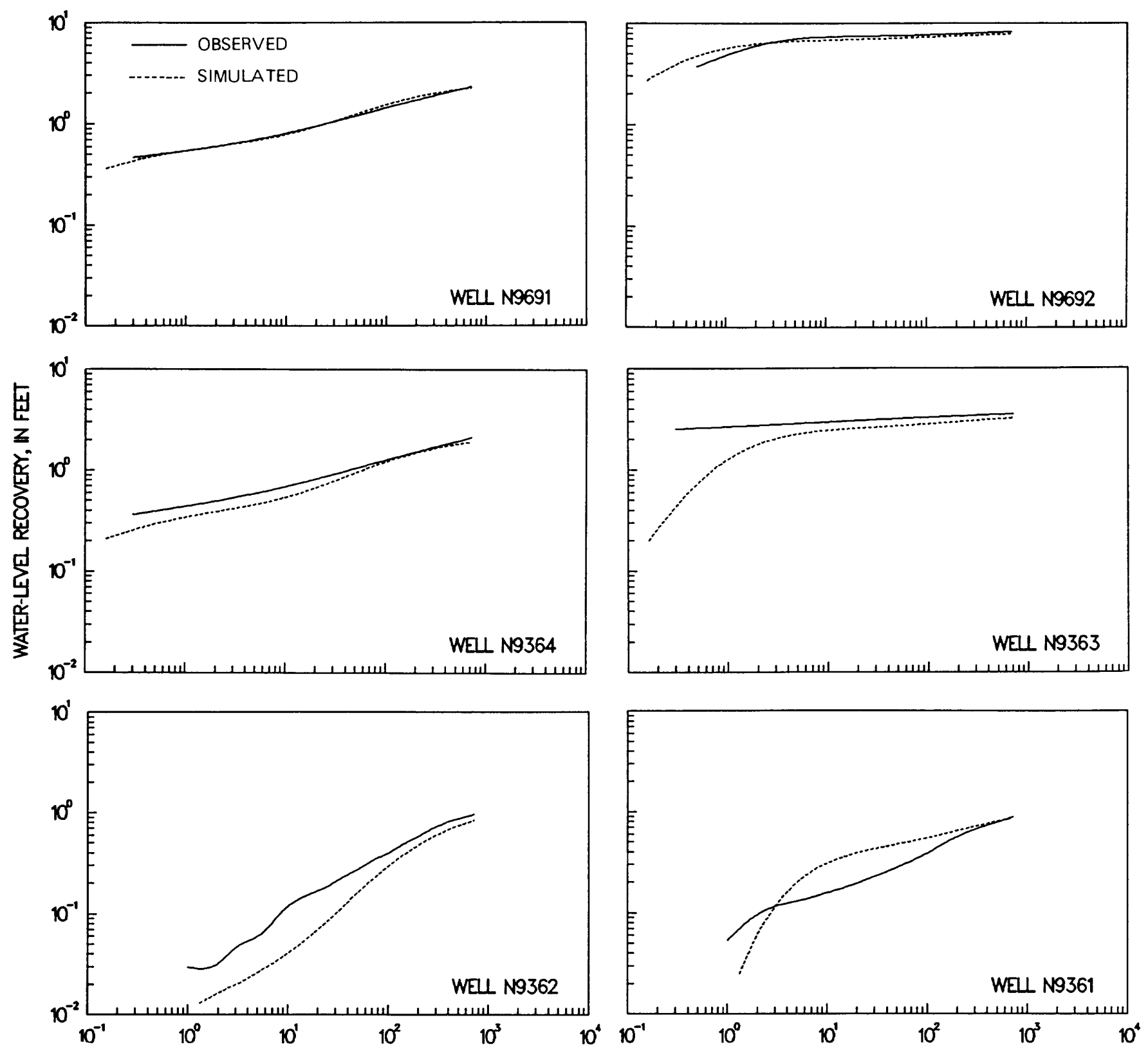

TIME SINCE PUMPING CEASED, IN MINUTES

Figure 19B.--Comparison of observed with simulated recoveries at observation wells in the Magothy aquifer test. (Well locations are shown in fig. 6.) 


\section{PUMPING CYCLE}

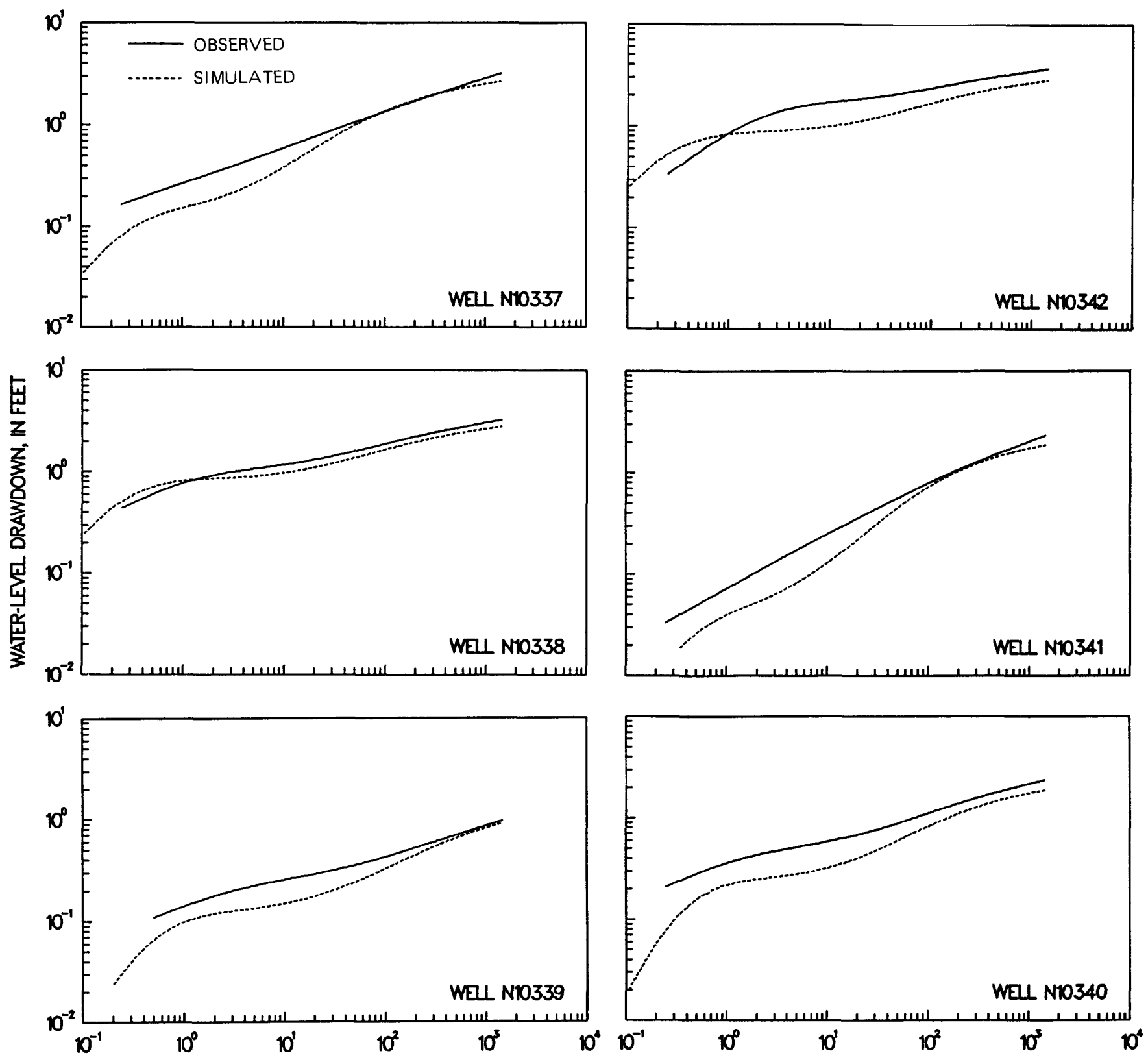

TIME SINCE PUMPNG BEGAN, N MINUTES

Figure 14A.--Comparison of observed with simulated drawdowns at observation wells in the upper glacial aquifer test. (Well locations are shown in fig. 7.) 


\section{RECOVERY CYCLE}
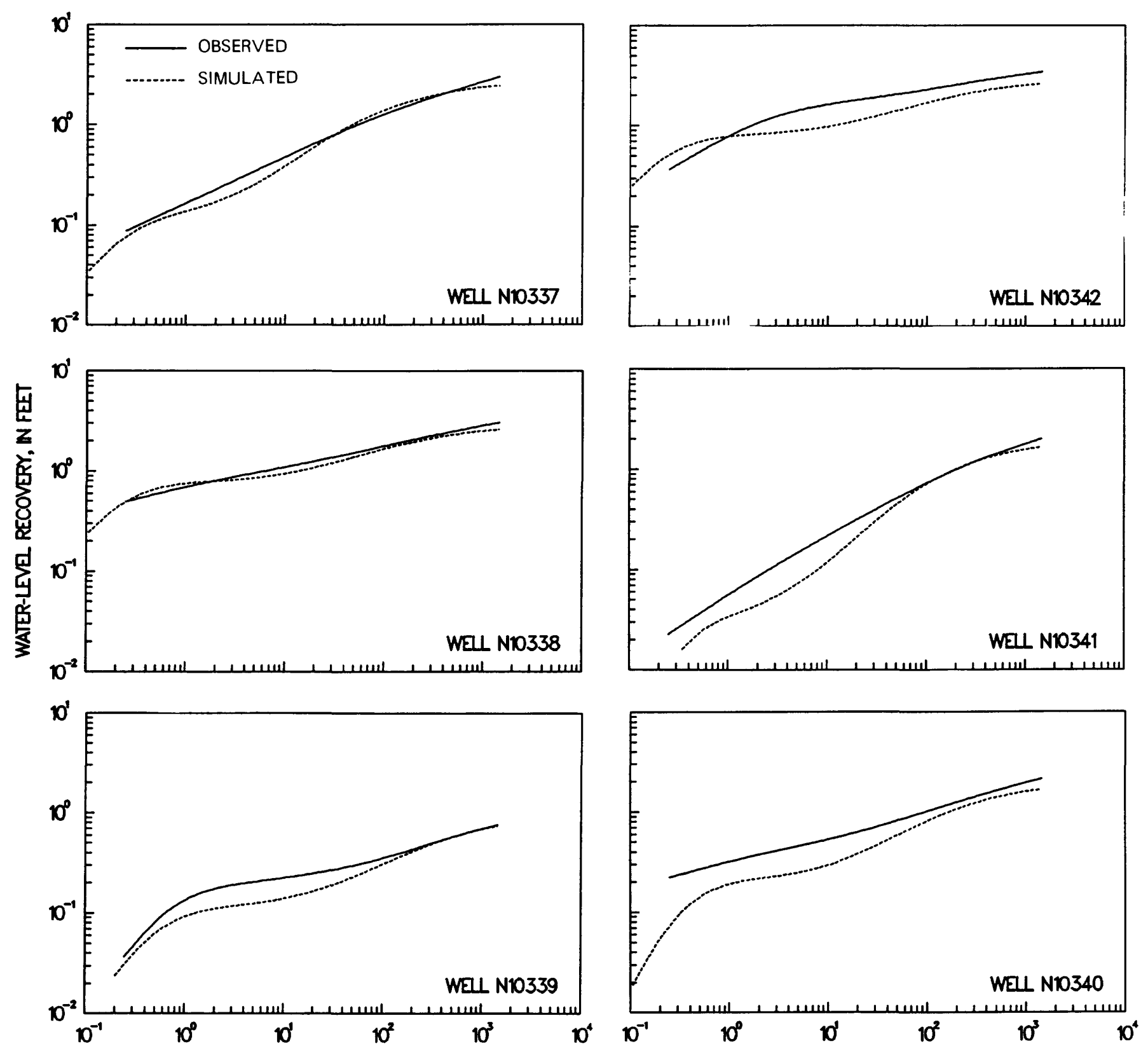

TIME SINCE PUMPING CEASED, IN MINUTES

Figure 14B.--Comparison of observed with simulated recoveries at observation wells in the upper glacial aquifer test. (Well locations are shown in fig. 7.) 


\section{RESULTS OF AQUIFER-TEST ANALYSIS}

The results of the analysis of the upper glacial and Magothy aquifer tests by the analytical, curve-matching, and numerical techniques yielded a relatively narrow range of values for aquifer characteristics; these are given in table 6. Radial hydraulic conductivity values for the upper glacial aquifer were between 380 and $562 \mathrm{ft} / \mathrm{d}$. The ratio of horizontal to vertical hydraulic conductivity was 2.8 to 3.8 , and the specific yield was 0.08 to 0.20. Horizontal hydraulic conductivity of the Magothy aquifer could be estimated only by the simple analytical solution and the numerical model; the resulting values ranged from 25 to $125 \mathrm{ft} / \mathrm{d}$, and the ratio of horizontal to vertical hydraulic conductivity (obtained from the numerical analysis) was 5.0 to 8.3. The specific storage of the Magothy aquifer was $5.0 \times 10^{-6} \mathrm{ft}^{-1}$ to $1.0 \times 10^{-4} \mathrm{ft}^{-1}$. Values for compressive storage in the upper glacial aquifer are not listed in table 6 because the simulated drawdowns in the model were insensitive to changes in this term and, as such, are not reliable.

The analytical solutions yield estimates quickly and can be useful when only rough estimates of aquifer properties are needed. The values obtained in this analysis should be used with caution, however, because the field conditions did not closely fit the assumptions upon which the analytical solutions are based. The lack of an impermeable base and the hydraulic interconnection of two aquifers are probably the greatest cause for error.

The estimates obtained from the curve-matching techniques should also be considered approximate because, again, the field conditions did not closely fit the assumptions upon which the curve-matching techniques are based. Some values of hydraulic conductivity and storativity obtained by the curvematching techniques were far beyond the range of published values for the upper glacial and Magothy aquifers. Values that seemed reasonable were close to values estimated by the other techniques, however. The "late" end of delayed-yield type curves gave aquifer-permeability and storativity values that closely matched those obtained by the other methods of analysis. The storage values obtained from the "early" part of the delayed-yield-type curves could not be confirmed, however.

The hydraulic values obtained through the numerical-model analysis may be considered the most reliable because this method can account for the local field conditions most accurately. This model also gives the most reliable "average" values for the various aquifer properties because the drawdowns at several observation points are matched simultaneously as closely as possible from a single set of aquifer coefficients. Sensitivity analyses indicated that the most reliable values are those that pertain to the aquifer being pumped, not those from the adjacent aquifer. Thus, the best results for the upper glacial aquifer were obtained from the upper glacial aquifer-test data, and the best results of the Magothy aquifer were obtained from the Magothy aquifer-test data. 


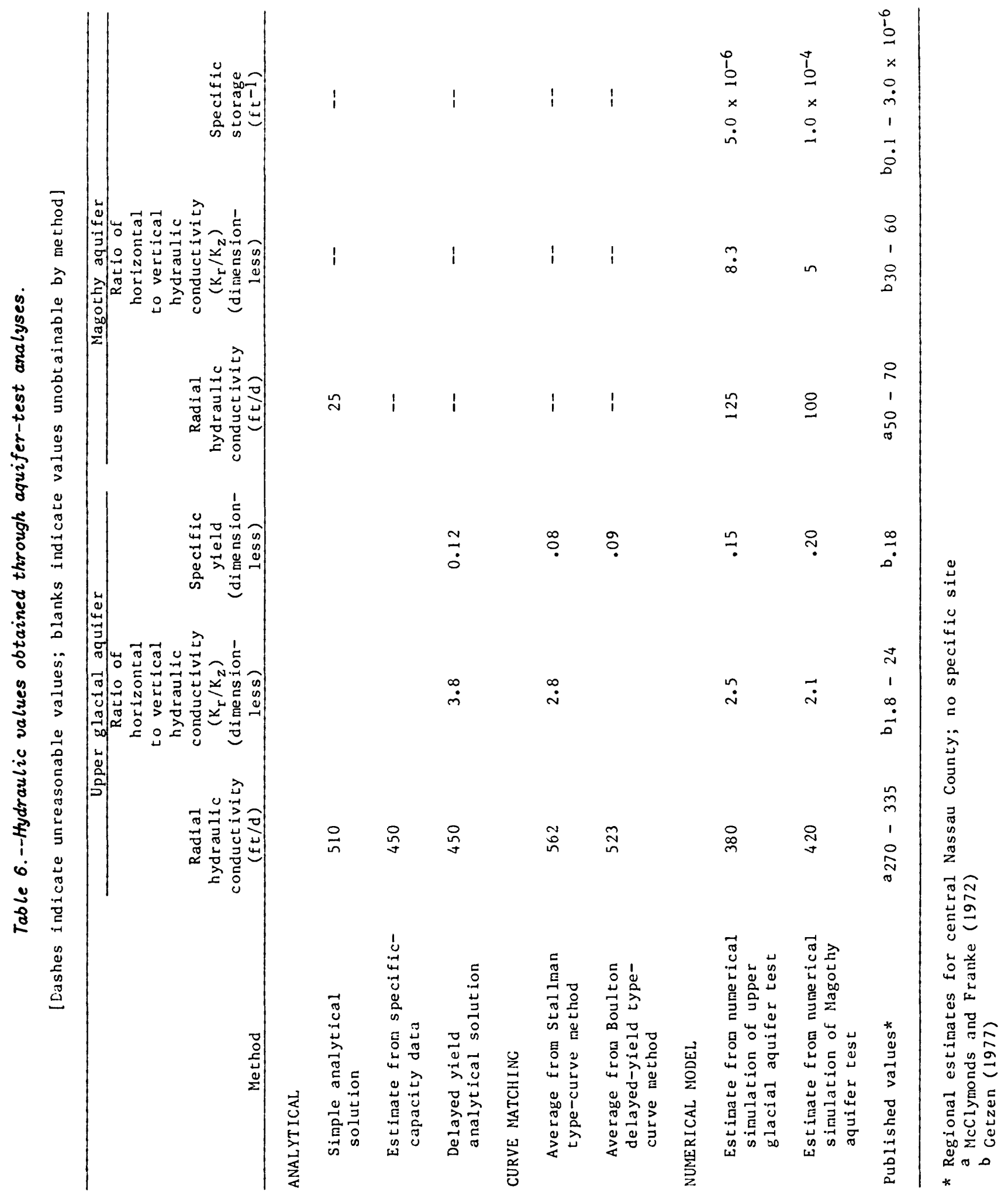




\section{SUMMARY AND CONCLUSIONS}

Data from pumping tests of the upper glacial aquifer in 1985 and the Magothy aquifer in 1978 at East Meadow were analyzed by six methods to determine hydraulic values for the two aquifers. The methods of analysis included two types of simple analytical solutions and an analytical solution that accounts for delayed gravity drainage; two type-curve matching techniques, one by the Stallman method, the other by the Boulton delayed-yield method; and simulation with a finite-element radial-flow model that used values obtained by the other methods as initial values. The finite-element model gave the most accurate results.

Ranges for the upper glacial aquifer obtained from all methods were as follows: radial hydraulic conductivity, 380 to $562 \mathrm{ft} / \mathrm{d}$; the ratio of horizontal to vertical hydraulic conductivity, 2.1 to 3.8 ; and specific yield, 0.08 to 0.20 . Ranges for the Magothy aquifer were as follows: horizontal hydraulic conductivity, 25 to $125 \mathrm{ft} / \mathrm{d}$; ratio of horizontal to vertical conductivity, 5.0 to 8.3 ; and specific storage, $5.0 \times 10^{-6} \mathrm{ft}^{-1}$ to $1.0 \times 10^{-4} \mathrm{ft}^{-1}$.

Results obtained from the analytical solutions and the curve-matching techniques are considered less accurate than those given by the numerical model because field conditions did not conform to the assumptions inherent in the analytical and curve-matching techniques. The lack of an impermeable boundary at the bottom of a homogeneous aquifer was probably the largest source of error. The chief advantage of these methods over the numerical model is the speed with which estimates can be made. Most of the estimates were relatively close to those obtained from the numerical model.

\section{REFERENCES CITED}

Aronson, D. A., Lindner, J. B., and Katz, B. G., 1983, Geohydrology of the Meadowbrook artificial-recharge site at East Meadow, Nassau County, New York: U.S. Geological Survey Water-Resources Investigations 82-4084, $44 \mathrm{p}$.

Bentall, Ray, 1963, Methods of determining permeability, transmissibility, and drawdown: U.S. Geological Survey Water-Supply Paper 1536-I, p. 245-247.

Boulton, N. S., 1963, Analysis of data from non-equilibrium pumping tests allowing for delayed yield from storage: London, Institute of Civil Engineers, proceedings, v. 26, p. 469-482.

Bredehoeft, J. D., 1963, Hydrogeology of the lower Humbolt River basin, Nevada: Reno, Nevada University, Desert Research Institute, Technical Report 3, 50 p.

Cooper, H. H., Jr., and Jacob, C. E., 1946, A generalized graphical method for evaluating formation constants and summarizing well-field history: American Geophysical Union Transactions, v. 27, no. 4, p. 526-534. 


\section{REFERENCES CITED (Continued)}

Franke, 0. L., and Cohen, Philip, 1972, Regional rates of ground-water movement on Long Island, New York: U.S. Geological Survey Professional Paper 800-C, p. C271-C277.

Franke, 0. L., and McClymonds, N. E., 1972, Summary of the hydrologic situation on Long Island, New York, as a guide to water-management alternatives: U.S. Geological Survey Professional Paper 627-F, 59 p.

Getzen, R. T., 1977, Analog-model analysis of regional three-dimensional flow in the ground-water reservoir of Long Island, New York: U.S. Geological Survey Professional Paper 982, 49 p.

Lindner, J. B., and Reilly, T. E., 1983, Analysis of three tests of the unconfined aquifer in southern Nassau County, Long Island, New York: U.S. Geological Survey Water-Resources Investigations Report 82-4021, 46 p.

Lohman, S. W., 1972, Ground water hydraulics: U.S. Geological Survey Professional Paper 708, 70 p.

Miller, J. F., and Frederick, R. H., 1969, The precipitation regime of Long Island, New York: U.S. Geological Survey Professional Paper 627-A, 21 p.

McClymonds, N. E., and Franke, O. L., 1972, Water-transmitting properties of aquifers on Long Island, New York: U.S. Geological Survey Professional Paper 627-E, $24 \mathrm{p}$.

Neuman, S. P., 1972, Theory of flow in unconfined aquifers considering delayed response of the water table: Water Resources Research, v. 8, no. 4, p. $1031-1045$.

1974, Effects of partial penetration on flow in unconfined aquifers considering delayed gravity response: Water-Resources Research, v. 10, no. 2 , p. 303-312.

1975, Analysis of pumping test data from anisotropic unconfined aquifers considering delayed gravity response: Water Resources Research, v. 11 , no. 2 , p. 326-342.

Perlmutter, N. M., and Geraghty, J. J., 1963, Geology and ground-water conditions in southern Nassau and southeastern Queens Counties, Long Island, New York: U.S. Geological Survey Water-Supp1y Paper 1613-A, 205 p.

Reilly, T. E., 1984, A Galerkin finite-element flow model to predict the transient response of a radially symmetric aquifer: U.S. Geological Survey Water-Supply Paper 2198, 33 p.

Todd, D. K., 1980, Groundwater hydrology: New York, John Wiley, 535 p. 
Appendix 1.--Data from Magothy aquifer test at East Meadow, N.Y., May 1978

[Well locations are shown in fig. 6.]

\begin{tabular}{|c|c|c|c|c|c|c|c|}
\hline & We11 & N9182 & & & We11 & N9183 & \\
\hline $\begin{array}{l}\text { Time since } \\
\text { start of } \\
\text { pumping } \\
\text { (minutes) }\end{array}$ & $\begin{array}{c}\text { Drawdown } \\
(\text { feet })\end{array}$ & $\begin{array}{c}\text { Time since } \\
\text { end of } \\
\text { pumping } \\
\text { (ninutes) }\end{array}$ & $\begin{array}{c}\text { Recovery } \\
(\text { feet })\end{array}$ & $\begin{array}{l}\text { Time since } \\
\text { start of } \\
\text { pumping } \\
\text { (ninutes) } \\
\end{array}$ & $\begin{array}{c}\text { Dr awdown } \\
\text { (feet) }\end{array}$ & $\begin{array}{c}\text { Time since } \\
\text { end of } \\
\text { pumping } \\
\text { (minutes) }\end{array}$ & $\begin{array}{c}\text { Recovery } \\
\text { (feet) }\end{array}$ \\
\hline 2 & 0 & 1 & 0 & 0 & 0.00 & 0 & 0.00 \\
\hline 3 & 0 & 2 & .04 & 2 & .01 & 1 & .01 \\
\hline 4 & 0 & 3 & .02 & 5 & .02 & 2 & .01 \\
\hline 5 & .01 & 4 & .01 & 6 & .01 & 3 & .00 \\
\hline 6 & .01 & 5 & .02 & 8 & .01 & 4 & .00 \\
\hline 7 & .01 & 6 & .02 & 9 & .01 & 5 & .01 \\
\hline 8 & .01 & 7 & .00 & 11 & .01 & 6 & .01 \\
\hline 9 & .01 & 8 & .01 & 14 & .01 & 7 & .01 \\
\hline 10 & .01 & 9 & .01 & 19 & .01 & 8 & .00 \\
\hline 11 & .01 & 10 & .03 & 24 & .01 & 9 & .00 \\
\hline 13 & .01 & 15 & .02 & 29 & .01 & 10 & .00 \\
\hline 14 & .01 & 20 & .03 & 39 & .01 & 15 & .01 \\
\hline 19 & .02 & 25 & .03 & 49 & .01 & 20 & .01 \\
\hline 24 & .02 & 30 & .01 & 59 & .01 & 25 & .01 \\
\hline 29 & .03 & 40 & .02 & 79 & .01 & 30 & .01 \\
\hline 39 & .03 & 50 & .03 & 100 & .00 & 40 & .01 \\
\hline 49 & .03 & 60 & .03 & 120 & .01 & 50 & .00 \\
\hline 59 & .04 & 80 & .04 & 150 & .01 & 60 & .01 \\
\hline 79 & .04 & 100 & .01 & 180 & .01 & 80 & .01 \\
\hline 100 & .04 & 120 & .02 & 240 & .02 & 100 & .02 \\
\hline 120 & .05 & 150 & .02 & 300 & .02 & 120 & .02 \\
\hline 150 & .06 & 180 & .03 & 360 & .03 & 150 & .01 \\
\hline 180 & .06 & & & 420 & .05 & 180 & .01 \\
\hline 240 & .07 & & & 480 & .06 & & \\
\hline 300 & .08 & & & 540 & .06 & & \\
\hline 360 & .09 & & & 600 & .07 & & \\
\hline 420 & .11 & & & 660 & .09 & & \\
\hline 480 & .12 & & & 715 & .09 & & \\
\hline 540 & .12 & & & & & & \\
\hline 600 & .12 & & & & & & \\
\hline 660 & .15 & & & & & & \\
\hline
\end{tabular}

- continued - 
Appendix 1.--Data from Magothy aquifer test at East Meadow, N.Y., May 1978--continued

[Well locations are shown in fig. 6.]

\begin{tabular}{|c|c|c|}
\hline \multicolumn{3}{|c|}{ We11 N9184 } \\
\hline $\begin{array}{l}\text { Tine since } \\
\text { start of } \\
\text { pumping } \\
\text { (minutes) } \\
\end{array}$ & $\begin{array}{c}\text { Dr awdown } \\
\text { (feet) }\end{array}$ & $\begin{array}{l}\text { Time sin } \\
\text { end of } \\
\text { pumping } \\
\text { (minutes }\end{array}$ \\
\hline 0 & 0.00 & 0 \\
\hline 2 & .01 & 1 \\
\hline 3 & .02 & 2 \\
\hline 4 & .02 & 3 \\
\hline 5 & .01 & 4 \\
\hline 6 & .03 & 5 \\
\hline 7 & .03 & 6 \\
\hline 8 & .03 & 7 \\
\hline 9 & .03 & 20 \\
\hline 10 & .02 & 25 \\
\hline 11 & .03 & 30 \\
\hline 13 & .03 & 40 \\
\hline 19 & .02 & 50 \\
\hline 24 & .04 & 60 \\
\hline 29 & .03 & 80 \\
\hline 39 & .03 & 100 \\
\hline 49 & .02 & 120 \\
\hline 59 & .03 & 150 \\
\hline 79 & .01 & 180 \\
\hline 100 & .02 & \\
\hline 120 & .02 & \\
\hline 150 & .02 & \\
\hline 180 & .02 & \\
\hline 240 & .03 & \\
\hline 300 & .03 & \\
\hline 360 & .05 & \\
\hline 420 & .06 & \\
\hline 480 & .06 & \\
\hline 540 & .07 & \\
\hline 600 & .08 & \\
\hline 660 & .10 & \\
\hline
\end{tabular}

\begin{tabular}{|c|c|c|c|}
\hline \multicolumn{4}{|c|}{ We11 N9360 } \\
\hline $\begin{array}{l}\text { Time since } \\
\text { start of } \\
\text { pumping } \\
\text { (ninutes) } \\
\end{array}$ & $\begin{array}{c}\text { Drawdown } \\
\text { (feet) }\end{array}$ & $\begin{array}{c}\text { Time since } \\
\text { end of } \\
\text { pumping } \\
\text { (minutes) }\end{array}$ & $\begin{array}{c}\text { Recovery } \\
(\text { feet })\end{array}$ \\
\hline 1 & 0.00 & 1 & 0.01 \\
\hline 2 & .00 & 2 & .01 \\
\hline 3 & .01 & 3 & .02 \\
\hline 4 & .01 & 4 & .03 \\
\hline 5 & .02 & 5 & .03 \\
\hline 6 & .03 & 6 & .04 \\
\hline 7 & .03 & 7 & .04 \\
\hline 8 & .03 & 8 & .04 \\
\hline 9 & .03 & 9 & .04 \\
\hline 10 & .04 & 11 & .05 \\
\hline 15 & .03 & 13 & .05 \\
\hline 20 & .05 & 15 & .06 \\
\hline 25 & .04 & 17 & .06 \\
\hline 30 & .04 & 19 & .06 \\
\hline 40 & .05 & 24 & .06 \\
\hline 50 & .05 & 29 & .06 \\
\hline 60 & .05 & 34 & .06 \\
\hline 80 & .07 & 39 & .06 \\
\hline 100 & .07 & 44 & .06 \\
\hline 120 & .07 & 49 & .07 \\
\hline 150 & .07 & 54 & .07 \\
\hline 180 & .09 & 59 & .06 \\
\hline 240 & .11 & 69 & .07 \\
\hline 300 & .13 & 79 & .07 \\
\hline 360 & .14 & 89 & .08 \\
\hline 420 & .17 & 99 & .08 \\
\hline 480 & .18 & 109 & .08 \\
\hline 542 & .19 & 119 & .08 \\
\hline 598 & .19 & 149 & .09 \\
\hline 630 & .20 & 181 & .11 \\
\hline 665 & .20 & 243 & .10 \\
\hline 715 & .22 & 300 & .10 \\
\hline & & 363 & .13 \\
\hline & & 420 & .13 \\
\hline & & 480 & .16 \\
\hline & & 540 & .16 \\
\hline & & 604 & .14 \\
\hline & & 661 & .15 \\
\hline & & 718 & .16 \\
\hline
\end{tabular}

- continued - 
Appendix 1.--Data from Magothy aquifer test at East Meadow, N.Y., May 1978--continued

[Well locations are shown in fig. 6.]

\begin{tabular}{|c|c|c|c|}
\hline & Well & N9361 & \\
\hline $\begin{array}{l}\text { Tine since } \\
\text { start of } \\
\text { pumping } \\
\text { (minutes) }\end{array}$ & $\begin{array}{c}\text { Dr awd own } \\
\text { (feet) }\end{array}$ & $\begin{array}{l}\text { Time since } \\
\text { end of } \\
\text { pumping } \\
\text { (minutes) }\end{array}$ & $\begin{array}{c}\text { Recovery } \\
\text { (feet) }\end{array}$ \\
\hline
\end{tabular}

\begin{tabular}{lccc}
\hline & Well N9362 & \\
\hline $\begin{array}{c}\text { Time since } \\
\text { start of }\end{array}$ & Time since & end of \\
pumping & $\begin{array}{c}\text { Drawdown } \\
\text { (feet) }\end{array}$ & $\begin{array}{c}\text { pumping } \\
\text { (minutes) }\end{array}$ & $\begin{array}{c}\text { Recovery } \\
\text { (minutes) }\end{array}$ \\
\hline
\end{tabular}

\begin{tabular}{|c|c|c|c|c|c|c|c|}
\hline 1 & 0.36 & 1 & 0.05 & 1 & 0.08 & 1 & 0.03 \\
\hline 2 & .44 & 2 & .11 & 2 & .10 & 2 & .03 \\
\hline 3 & .46 & 3 & .11 & 3 & .12 & 3 & .05 \\
\hline 4 & .47 & 4 & .14 & 4 & .13 & 5 & .06 \\
\hline 5 & .49 & 5 & .12 & 5 & .13 & 6 & .06 \\
\hline 6 & .50 & 6 & .12 & 6 & .14 & 7 & .09 \\
\hline 7 & .49 & 8 & .15 & 7 & .14 & 8 & .09 \\
\hline 9 & .51 & 9 & .16 & 8 & .15 & 9 & .12 \\
\hline 10 & .53 & 11 & .17 & 9 & .17 & 11 & .12 \\
\hline 15 & .57 & 13 & .16 & 10 & .17 & 13 & .15 \\
\hline 20 & .59 & 15 & .18 & 15 & .20 & 15 & .14 \\
\hline 25 & .66 & 17 & .18 & 20 & .23 & 17 & .16 \\
\hline 30 & .63 & 19 & .18 & 25 & .27 & 19 & .17 \\
\hline 40 & .67 & 24 & .22 & 30 & .27 & 24 & .17 \\
\hline 50 & .69 & 29 & .23 & 40 & .33 & 29 & .21 \\
\hline 60 & .72 & 34 & .23 & 50 & .36 & 34 & .23 \\
\hline 80 & .78 & 39 & .24 & 60 & .40 & 39 & .23 \\
\hline 100 & .84 & 44 & .27 & 80 & .49 & 44 & .26 \\
\hline 120 & .85 & 49 & .28 & 100 & .53 & 49 & .27 \\
\hline 150 & .90 & 54 & .29 & 120 & .59 & 54 & .28 \\
\hline 180 & .95 & 59 & .31 & 150 & .66 & 59 & .29 \\
\hline 190 & .95 & 69 & .32 & 180 & .72 & 69 & .35 \\
\hline 250 & 1.10 & 79 & .33 & 240 & .83 & 79 & .37 \\
\hline 310 & 1.07 & 89 & .36 & 300 & .92 & 89 & .36 \\
\hline 370 & 1.12 & 99 & .37 & 360 & .99 & 99 & .38 \\
\hline 430 & 1.17 & 109 & .39 & 420 & 1.07 & 109 & .40 \\
\hline 492 & 1.22 & 119 & .42 & 480 & 1.13 & 119 & .46 \\
\hline 548 & 1.27 & 149 & .52 & 542 & 1.17 & 149 & .51 \\
\hline 615 & 1.39 & 181 & .55 & 598 & 1.22 & 181 & .54 \\
\hline \multirow[t]{9}{*}{664} & 1.40 & 243 & .63 & 630 & 1.25 & 243 & .65 \\
\hline & & 300 & .66 & 665 & 1.25 & 300 & .73 \\
\hline & & 363 & .72 & 714 & 1.27 & 363 & .77 \\
\hline & & 420 & .74 & & & 420 & .87 \\
\hline & & 480 & .76 & & & 480 & .85 \\
\hline & & 540 & .78 & & & 540 & .87 \\
\hline & & 604 & .82 & & & 661 & .96 \\
\hline & & 661 & .87 & & & 718 & .96 \\
\hline & & 718 & .90 & & & & \\
\hline
\end{tabular}


Appendix 1.--Data from Magothy aquifer test at East Meadow, N.Y., May 1978--continued

[Well locations are shown in fig. 6.]

\begin{tabular}{|c|c|c|c|}
\hline & We1 & N9363 & \\
\hline $\begin{array}{l}\text { Time since } \\
\text { start of } \\
\text { pumping } \\
\text { (minutes) }\end{array}$ & $\begin{array}{c}\text { Dr awdown } \\
\text { (feet) }\end{array}$ & $\begin{array}{l}\text { Time since } \\
\text { end of } \\
\text { pumping } \\
\text { (minutes) }\end{array}$ & $\begin{array}{c}\text { Recovery } \\
\text { (feet) }\end{array}$ \\
\hline
\end{tabular}

\begin{tabular}{|c|c|c|c|c|c|c|c|}
\hline 2 & 2.96 & 2 & 2.77 & 2 & 0.53 & 1 & 0.44 \\
\hline 3 & 2.68 & 3 & 2.80 & 3 & .49 & 2 & .44 \\
\hline 4 & 2.69 & 4 & 2.81 & 4 & .49 & 3 & .51 \\
\hline 5 & 2.72 & 5 & 2.81 & 5 & .59 & 4 & .55 \\
\hline 6 & 2.75 & 6 & 2.84 & 6 & .59 & 5 & .57 \\
\hline 8 & 2.77 & 8 & 2.87 & 8 & .60 & 6 & .59 \\
\hline 10 & 2.80 & 10 & 2.89 & 10 & .66 & 8 & .64 \\
\hline 15 & 2.87 & 12 & 2.90 & 15 & .70 & 10 & .67 \\
\hline 21 & 2.92 & 14 & 2.92 & 21 & .78 & 12 & .70 \\
\hline 26 & 2.95 & 16 & 2.93 & 26 & .85 & 14 & .73 \\
\hline 31 & 3.00 & 18 & 2.94 & 31 & .89 & 16 & .75 \\
\hline 41 & 3.07 & 20 & 2.95 & 41 & 1.00 & 18 & .78 \\
\hline 51 & 3.11 & 25 & 2.96 & 51 & 1.00 & 20 & .80 \\
\hline 56 & 3.12 & 30 & 3.00 & 56 & 1.07 & 25 & .85 \\
\hline 81 & 3.23 & 35 & 3.02 & 81 & 1.22 & 30 & .93 \\
\hline 101 & 3.28 & 40 & 3.04 & 101 & 1.30 & 35 & .95 \\
\hline 111 & 3.30 & 45 & 3.06 & 111 & 1.36 & 40 & 1.00 \\
\hline 121 & 3.32 & 50 & 3.09 & 121 & 1.39 & 45 & 1.02 \\
\hline 141 & 3.36 & 55 & 3.10 & 141 & 1.46 & 50 & 1.05 \\
\hline 161 & 3.40 & 60 & 3.12 & 161 & 1.53 & 55 & 1.09 \\
\hline 181 & 3.43 & 70 & 3.14 & 181 & 1.60 & 60 & 1.13 \\
\hline 211 & 3.47 & 80 & 3.17 & 211 & 1.70 & 70 & 1.18 \\
\hline 241 & 3.52 & 90 & 3.20 & 241 & 1.77 & 80 & 1.23 \\
\hline 271 & 3.58 & 100 & 3.23 & 271 & 1.84 & 90 & 1.27 \\
\hline 301 & 3.63 & 110 & 3.24 & 301 & 1.86 & 100 & 1.31 \\
\hline 331 & 3.64 & 120 & 3.25 & 331 & 1.90 & 110 & 1.36 \\
\hline 361 & 3.67 & 140 & 3.30 & 351 & 1.94 & 120 & 1.39 \\
\hline 391 & 3.71 & 165 & 3.36 & 391 & 1.97 & 140 & 1.45 \\
\hline 421 & 3.73 & 180 & 3.38 & 421 & 2.02 & 165 & 1.54 \\
\hline 451 & 3.76 & 240 & 3.44 & 451 & 2.05 & 180 & 1.57 \\
\hline 481 & 3.81 & 300 & 3.51 & 481 & 2.10 & 240 & 1.64 \\
\hline 511 & 3.82 & 357 & 3.54 & 511 & 2.12 & 300 & 1.74 \\
\hline 540 & 3.87 & 419 & 3.59 & 540 & 2.15 & 357 & 1.83 \\
\hline 570 & 3.87 & 478 & 3.65 & 570 & 2.16 & 419 & 1.90 \\
\hline 601 & 3.90 & 535 & 3.67 & 601 & 2.19 & 478 & 1.94 \\
\hline 662 & 3.94 & 602 & 3.69 & 662 & 2.28 & 535 & 1.97 \\
\hline 696 & 3.94 & 660 & 3.81 & 696 & 2.28 & 602 & 1.98 \\
\hline \multirow[t]{2}{*}{715} & 3.96 & 722 & 3.76 & 715 & 2.29 & 660 & 2.04 \\
\hline & & & & & & 722 & 2.06 \\
\hline
\end{tabular}

\begin{tabular}{|c|c|c|c|}
\hline & We11 & N9364 & \\
\hline $\begin{array}{l}\text { Time since } \\
\text { start of } \\
\text { pumping } \\
\text { (minutes) }\end{array}$ & $\begin{array}{c}\text { Dr awdown } \\
\text { (feet) }\end{array}$ & $\begin{array}{l}\text { Time since } \\
\text { end of } \\
\text { pumping } \\
\text { (minutes) }\end{array}$ & $\begin{array}{c}\text { Recovery } \\
\text { (feet) }\end{array}$ \\
\hline
\end{tabular}

.55

.57

.67

.70

.78

.80

93

.95

.00

.13

.18

.31

.36

1.39

1.54

.57

64

1.74

.94

1.97

.98

.04
2.06 
Appendix 1.--Data from Magothy aquifer test at East Meadow, N.Y., May 1978--continued

[Well locations are shown in fig. 6.]

\begin{tabular}{|c|c|c|c|c|c|c|c|}
\hline \multicolumn{4}{|c|}{ Wel1 N9691 } & \multicolumn{4}{|c|}{ We11 N9692 } \\
\hline $\begin{array}{l}\text { Time since } \\
\text { start of } \\
\text { pumping } \\
\text { (minutes) } \\
\end{array}$ & $\begin{array}{c}\text { Drawdown } \\
(\text { feet })\end{array}$ & $\begin{array}{l}\text { Time since } \\
\text { end of } \\
\text { pumping } \\
\text { (minutes) }\end{array}$ & $\begin{array}{c}\text { Recovery } \\
\text { (feet) }\end{array}$ & $\begin{array}{c}\text { Time since } \\
\text { start of } \\
\text { pumping } \\
\text { (minutes) } \\
\end{array}$ & $\begin{array}{c}\text { Dr awdown } \\
(\text { feet })\end{array}$ & $\begin{array}{l}\text { Time since } \\
\text { end of } \\
\text { pumping } \\
\text { (minutes) }\end{array}$ & $\begin{array}{c}\text { Recovery } \\
(\text { feet })\end{array}$ \\
\hline 0.25 & 0.51 & 0.30 & 0.60 & 0.25 & 2.22 & 0.50 & 2.94 \\
\hline .50 & .56 & 1 & .53 & .5 & 4.58 & 1 & 5.67 \\
\hline 1 & .61 & 2 & .57 & 1 & 6.38 & 2 & 6.67 \\
\hline 2 & .58 & 3 & .61 & 2 & 6.78 & 3 & 7.04 \\
\hline 3 & .62 & 4 & .65 & 3 & 6.90 & 4 & 7.15 \\
\hline 4 & .66 & 5 & .66 & 4 & 6.97 & 5 & 7.21 \\
\hline 5 & .68 & 6 & .69 & 5 & 7.01 & 6 & 7.22 \\
\hline 6 & .69 & 8 & .73 & 6 & 7.04 & 8 & 7.24 \\
\hline 8 & .73 & 10 & .77 & 8 & 7.13 & 10 & 7.29 \\
\hline 10 & .76 & 12 & .81 & 10 & 7.15 & 12 & 7.30 \\
\hline 12 & .79 & 14 & .84 & 12 & 7.19 & 14 & 7.32 \\
\hline 14 & .82 & 16 & .87 & 14 & 7.23 & 16 & 7.33 \\
\hline 16 & .85 & 18 & .90 & 16 & 7.26 & 20 & 7.34 \\
\hline 18 & .86 & 20 & .93 & 18 & 7.28 & 30 & 7.38 \\
\hline 20 & .89 & 25 & .98 & 20 & 7.32 & 35 & 7.42 \\
\hline 25 & .94 & 30 & 1.04 & 25 & 7.39 & 40 & 7.46 \\
\hline 30 & .99 & 35 & 1.08 & 30 & 7.43 & 45 & 7.49 \\
\hline 35 & 1.03 & 40 & 1.13 & 35 & 7.48 & 50 & 7.51 \\
\hline 40 & 1.09 & 45 & 1.18 & 40 & 7.52 & 55 & 7.53 \\
\hline 45 & 1.13 & 50 & 1.19 & 45 & 7.58 & 60 & 7.55 \\
\hline 50 & 1.16 & 55 & 1.24 & 50 & 7.61 & 70 & 7.58 \\
\hline 60 & 1.24 & 60 & 1.27 & 60 & 7.66 & 80 & 7.62 \\
\hline 80 & 1.37 & 70 & 1.33 & 80 & 7.77 & 90 & 7.65 \\
\hline 100 & 1.47 & 80 & 1.38 & 100 & 7.82 & 100 & 7.69 \\
\hline 110 & 1.52 & 90 & 1.43 & 110 & 7.83 & 110 & 7.71 \\
\hline 120 & 1.57 & 100 & 1.48 & 120 & 7.86 & 120 & 7.73 \\
\hline 140 & 1.65 & 110 & 1.52 & 140 & 7.91 & 140 & 7.78 \\
\hline 160 & 1.71 & 120 & 1.56 & 160 & 7.94 & 168 & 7.85 \\
\hline 180 & 1.78 & 141 & 1.60 & 180 & 7.98 & 180 & 7.83 \\
\hline 210 & 1.84 & 167 & 1.69 & 210 & 8.05 & 238 & 7.93 \\
\hline 240 & 1.92 & 180 & 1.72 & 240 & 8.11 & 298 & 8.03 \\
\hline 270 & 1.99 & 237 & 1.82 & 270 & 8.12 & 355 & 8.08 \\
\hline 300 & 2.04 & 299 & 1.93 & 300 & 8.16 & 417 & 8.15 \\
\hline 330 & 2.08 & 355 & 1.99 & 330 & 8.19 & 476 & 8.17 \\
\hline 360 & 2.13 & 417 & 2.04 & 360 & 8.23 & 532 & 8.18 \\
\hline 430 & 2.22 & 476 & 2.11 & 430 & 8.32 & 597 & 8.21 \\
\hline 490 & 2.29 & 530 & 2.12 & 490 & 8.36 & 654 & 8.21 \\
\hline 550 & 2.34 & 598 & 2.17 & 582 & 8.42 & 709 & 8.30 \\
\hline 650 & 2.39 & 711 & 2.23 & 650 & 8.46 & & \\
\hline 750 & 2.42 & & & 750 & 8.51 & & \\
\hline
\end{tabular}


Appendix 2.--Data from upper glacial aquifer test at East Meadow, July 1985.

[We11 locations are shown on $\mathrm{fig} \cdot 7]$

\begin{tabular}{|c|c|c|c|}
\hline & Well & $\mathrm{N} 10337$ & \\
\hline $\begin{array}{l}\text { Time since } \\
\text { start of } \\
\text { pumping } \\
\text { (ninutes) }\end{array}$ & $\begin{array}{c}\text { Drawdown } \\
\text { (feet) }\end{array}$ & $\begin{array}{c}\text { Time since } \\
\text { end of } \\
\text { pumping } \\
\text { (minutes) }\end{array}$ & $\begin{array}{c}\text { Recove ry } \\
(\text { feet })\end{array}$ \\
\hline
\end{tabular}

0

$\begin{array}{lrr}0 & 0 & 0 \\ .25 & .17 & . \\ .5 & .22 & . \\ .75 & .25 & .7 \\ 1.0 & .27 & 1 . \\ 1.5 & .31 & 1 . \\ 2 & .34 & 2 \\ 3 & .38 & 3 \\ 4 & .42 & 4 \\ 5 & .44 & 5 \\ 7 & .49 & 7 \\ 9 & .53 & 9 \\ 2 & .59 & 12 \\ 5 & .64 & 15 \\ 0 & .72 & 20 \\ 25 & .79 & 25 \\ 0 & .86 & 30 \\ 5 & .92 & 35 \\ 0 & .97 & 40 \\ 5 & 1.02 & 45 \\ 0 & 1.07 & 50 \\ 0 & 1.16 & 60 \\ 5 & 1.27 & 75 \\ 0 & 1.37 & 90 \\ 5 & 1.46 & 105 \\ 0 & 1.55 & 120 \\ 0 & 1.68 & 150 \\ 0 & 1.78 & 180 \\ 0 & 1.86 & 210 \\ 0 & 1.93 & 240 \\ 0 & 2.06 & 300 \\ 0 & 2.16 & 360 \\ 0 & 2.25 & 420 \\ 0 & 2.39 & 540 \\ 0 & 2.50 & 660 \\ 0 & 2.58 & 780 \\ 0 & 2.65 & 900 \\ 0 & 2.74 & 1080 \\ 0 & 2.84 & 1320 \\ 0 & & 1440\end{array}$

0

.09

.12

.14

.16

.20

.23

.27

.30

.34

.39

.44

.50

.56

.64

.70

.77

.82

.90

.96

1.00

1.09

1.20

1. 30

1.38

1.46

1.58

1.68

1.76

1.82

1.93

2.03

2.10

2.23

2.33

2.40

2.45

2.56

2.57

2.59

\begin{tabular}{|c|c|c|c|}
\hline & Well & 10338 & \\
\hline $\begin{array}{l}\text { Tine since } \\
\text { start of } \\
\text { pumping } \\
\text { (ninutes) }\end{array}$ & $\begin{array}{c}\text { Drawdown } \\
\text { (feet) }\end{array}$ & $\begin{array}{l}\text { Time since } \\
\text { end of } \\
\text { pumping } \\
\text { (minutes) }\end{array}$ & $\begin{array}{c}\text { Recovery } \\
\text { (feet) }\end{array}$ \\
\hline
\end{tabular}

0
.35

.64

.79

.86

.93

.96

1.00

1.00

1.06

1.11

1.14

1.18

1.23

1.29

1.34

1.40

1.47

1.50

1.57

1.61

1.67

1.78

1.86

1.96

2.01

2.14

2.22

2.30

2.38

2.48

2.59

2.66

2.77

2.88

2.96

3.00

3.10

3.19

3.20
0

.25

.5

.75

1.5

2

3$$
\begin{aligned}
& 4 \\
& 5
\end{aligned}
$$

$$
7
$$$$
\begin{array}{r}
9 \\
12
\end{array}
$$$$
\begin{aligned}
& 12 \\
& 15 \\
& 20
\end{aligned}
$$$$
\begin{aligned}
& 20 \\
& 25
\end{aligned}
$$$$
\begin{aligned}
& 25 \\
& 30
\end{aligned}
$$$$
\begin{aligned}
& 30 \\
& 35
\end{aligned}
$$$$
\begin{aligned}
& 35 \\
& 40
\end{aligned}
$$$$
\begin{aligned}
& 40 \\
& 45
\end{aligned}
$$$$
\begin{aligned}
& 45 \\
& 50
\end{aligned}
$$$$
60
$$$$
\begin{aligned}
& 60 \\
& 75
\end{aligned}
$$$$
\begin{array}{r}
75 \\
90
\end{array}
$$$$
105
$$$$
120
$$$$
150
$$$$
180
$$$$
210
$$$$
\begin{aligned}
& 210 \\
& 240
\end{aligned}
$$$$
300
$$$$
360
$$$$
420
$$$$
540
$$$$
660
$$$$
780
$$$$
900
$$$$
1080
$$$$
1320
$$$$
1440
$$$$
1320
$$$$
1440
$$

0

.40

.61

.71

.77

.82

.85

.89

.93

.95

1.00

1.03

1.11

1.15

1.21

1. 28

1. 34

1.38

1.43

1.47

1.51

1.58

1.68

1.77

1.84

1.90

2.01

2.09

2.18

2.24

2.35

2.43

2.50

2.58

2.66

2.72

2.78

2.83

2.89

2.91

(continued) 
Appendix 2.--Data from upper glacial aquifer test at East Meadow, July 1985--continued.

[Well locations are shown on fig. 7]

\begin{tabular}{|c|c|c|c|}
\hline & Well & N10339 & \\
\hline $\begin{array}{l}\text { Time since } \\
\text { start of } \\
\text { pumping } \\
\text { (minutes) }\end{array}$ & $\begin{array}{c}\text { Drawdown } \\
\text { (feet) }\end{array}$ & $\begin{array}{l}\text { Tine since } \\
\text { end of } \\
\text { pumping } \\
\text { (ninutes) }\end{array}$ & $\begin{array}{c}\text { Recove ry } \\
\text { (feet) }\end{array}$ \\
\hline
\end{tabular}

\begin{tabular}{|c|c|c|c|}
\hline 0 & 0 & 0 & 0 \\
\hline .25 & 0 & .25 & .03 \\
\hline .5 & .09 & .5 & .10 \\
\hline .75 & .13 & .75 & .12 \\
\hline 1.0 & .15 & 1.0 & .14 \\
\hline 1.5 & .18 & 1.5 & .16 \\
\hline 2 & .19 & 2 & .17 \\
\hline 3 & .21 & 3 & .18 \\
\hline 4 & .22 & 4 & .20 \\
\hline 5 & .23 & 5 & .20 \\
\hline 7 & .24 & 7 & .21 \\
\hline 9 & .24 & 9 & .22 \\
\hline 12 & .26 & 12 & .23 \\
\hline 15 & .27 & 15 & .24 \\
\hline 20 & .28 & 20 & .25 \\
\hline 25 & .29 & 25 & .26 \\
\hline 30 & .30 & 30 & .27 \\
\hline 35 & .31 & 35 & .28 \\
\hline 40 & .32 & 40 & .28 \\
\hline 45 & .34 & 45 & .29 \\
\hline 50 & .34 & 50 & .30 \\
\hline 60 & .36 & 60 & .31 \\
\hline 75 & .38 & 75 & .33 \\
\hline 90 & .41 & 90 & .34 \\
\hline 05 & .43 & 105 & .36 \\
\hline 20 & .45 & 120 & .37 \\
\hline 50 & .48 & 150 & .40 \\
\hline 80 & .52 & 180 & .42 \\
\hline 10 & .54 & 210 & .44 \\
\hline 40 & .56 & 240 & .46 \\
\hline 00 & .60 & 300 & .50 \\
\hline 60 & .64 & 360 & .53 \\
\hline 20 & .66 & 420 & .56 \\
\hline 40 & .72 & 540 & .59 \\
\hline 60 & .78 & 660 & .62 \\
\hline 80 & .82 & 780 & .65 \\
\hline 00 & .84 & 900 & .68 \\
\hline 80 & .88 & 1080 & .71 \\
\hline 20 & .94 & 1320 & .74 \\
\hline 40 & .95 & 1440 & .75 \\
\hline
\end{tabular}

\begin{tabular}{llll}
\hline & Well N10340 & \\
\hline $\begin{array}{c}\text { Time since } \\
\text { start of } \\
\text { pumping } \\
\text { (minutes) }\end{array}$ & $\begin{array}{c}\text { Drawdown } \\
\text { (feet) }\end{array}$ & $\begin{array}{c}\text { end of } \\
\text { (nimping }\end{array}$ & $\begin{array}{c}\text { Recovery } \\
\text { (feet) }\end{array}$ \\
\hline
\end{tabular}

$\begin{array}{rrrr}0 & 0 & 0 & 0 \\ .25 & .17 & .25 & .19 \\ .5 & .30 & .5 & .28 \\ .75 & .37 & .75 & .33 \\ 1.0 & .40 & 1.0 & .35 \\ 1.5 & .42 & 1.5 & .38 \\ 2 & .44 & 2 & .39 \\ 3 & .47 & 3 & .41 \\ 4 & .49 & 4 & .43 \\ 5 & .50 & 5 & .45 \\ 7 & .54 & 7 & .48 \\ 9 & .56 & 9 & .50 \\ 12 & .59 & 12 & .53 \\ 15 & .62 & 15 & .56 \\ 20 & .66 & 20 & .60 \\ 25 & .70 & 25 & .64 \\ 30 & .74 & 30 & .68 \\ 35 & .77 & 35 & .71 \\ 40 & .80 & 40 & .74 \\ 45 & .84 & 45 & .77 \\ 50 & .87 & 50 & .80 \\ 60 & .93 & 60 & .85 \\ 75 & 1.01 & 75 & .92 \\ 90 & 1.08 & 90 & .99 \\ 105 & 1.14 & 105 & 1.04 \\ 120 & 1.20 & 120 & 1.10 \\ 150 & 1.30 & 150 & 1.18 \\ 130 & 1.37 & 180 & 1.25 \\ 210 & 1.43 & 210 & 1.32 \\ 240 & 1.49 & 240 & 1.37 \\ 300 & 1.59 & 300 & 1.46 \\ 360 & 1.67 & 360 & 1.54 \\ 420 & 1.74 & 420 & 1.60 \\ 540 & 1.86 & 540 & 1.69 \\ 660 & 1.96 & 660 & 1.78 \\ 780 & 2.04 & 780 & 1.84 \\ 900 & 2.10 & 900 & 1.89 \\ 1080 & 2.18 & 1080 & 1.94 \\ 1320 & 2.28 & 1320 & 2.00 \\ 1440 & 2.30 & 1440 & 2.02\end{array}$

\footnotetext{
- continued -
} 
Appendix 2.--Data from upper glacial aquifer test at East Meadow, July 1985--continued.

[Well locations are shown on fig. 7]

\begin{tabular}{|c|c|c|c|}
\hline & Wel1 & 1.10341 & \\
\hline $\begin{array}{l}\text { Time since } \\
\text { start of } \\
\text { punping } \\
\text { (minutes) }\end{array}$ & $\begin{array}{c}\text { Drawdown } \\
\text { (feet) }\end{array}$ & $\begin{array}{l}\text { Time since } \\
\text { end of } \\
\text { pumping } \\
\text { (minutes) }\end{array}$ & $\begin{array}{c}\text { Recove ry } \\
\text { (feet) }\end{array}$ \\
\hline
\end{tabular}

$\begin{array}{lccc}0 & 0 & 0 & 0 \\ .25 & .03 & .25 & .02 \\ .5 & .05 & .5 & .03 \\ .75 & .06 & .75 & .05 \\ 1.0 & .07 & 1.0 & .06 \\ 1.5 & .09 & 1.5 & .07 \\ 2 & .10 & 2 & .09 \\ 3 & .14 & 3 & .11 \\ 4 & .16 & 4 & .13 \\ 5 & .18 & 5 & .14 \\ 7 & .21 & 7 & .18 \\ 9 & .24 & 9 & .20 \\ 12 & .27 & 12 & .23 \\ 15 & .30 & 15 & .26 \\ 20 & .34 & 20 & .30 \\ 25 & .38 & 25 & .34 \\ 30 & .42 & 30 & .38 \\ 35 & .45 & 35 & .41 \\ 40 & .49 & 40 & .44 \\ 45 & .52 & 45 & .47 \\ 50 & .56 & 50 & .50 \\ 60 & .63 & 60 & .56 \\ 75 & .72 & 75 & .62 \\ 90 & .79 & 90 & .69 \\ 105 & .86 & 105 & .76 \\ 120 & .92 & 120 & .82 \\ 150 & 1.03 & 150 & .92 \\ 180 & 1.12 & 180 & 1.05 \\ 210 & 1.19 & 210 & 1.08 \\ 240 & 1.25 & 240 & 1.15 \\ 300 & 1.35 & 300 & 1.24 \\ 360 & 1.44 & 360 & 1.33 \\ 420 & 1.52 & 420 & 1.40 \\ 540 & 1.64 & 540 & 1.49 \\ 660 & 1.75 & 660 & 1.57 \\ 780 & 1.81 & 780 & 1.63 \\ 900 & 1.88 & 900 & 1.68 \\ 080 & 1.96 & 1080 & 1.73 \\ 320 & 2.06 & 1320 & 1.79 \\ 440 & 2.08 & 1440 & 1.82\end{array}$

\begin{tabular}{|c|c|c|c|}
\hline \multicolumn{4}{|c|}{ We11 N10342 } \\
\hline $\begin{array}{l}\text { Time since } \\
\text { start of } \\
\text { pumping } \\
\text { (minutes) }\end{array}$ & $\begin{array}{c}\text { Drawdown } \\
\text { (feet) }\end{array}$ & $\begin{array}{c}\text { Time since } \\
\text { end of } \\
\text { pumping } \\
\text { (ninutes) }\end{array}$ & $\begin{array}{c}\text { Re cove ry } \\
\text { (feet) }\end{array}$ \\
\hline
\end{tabular}

0

0

$\begin{array}{ll}.25 & .27 \\ .5 & .56\end{array}$

$.75 \quad .77$

$\begin{array}{ll}1.0 & .94 \\ 1.5 & 1.18\end{array}$

$\begin{array}{ll}1.5 & 1.18 \\ 2 & 1.32\end{array}$

$3 \quad 1.48$

1.55

1.58

1.63

1.66

1.70

1.74

1.80

1.86

1.90

1.95

1.99

2.03

2.06

2.14

2.23

2.32

2.39

2.46

2.56

2.65

2.72

2.78

2.88

3.00

3.07

3.20

3.30

3.37

3.44

3.52

3.61

3.62
0

0

$\begin{array}{ll}.25 & .30 \\ .5 & .52\end{array}$

$\begin{array}{ll}.5 & .52 \\ .75 & .69\end{array}$

$1.0 \quad .84$

$1.5 \quad 1.06$

21.20

$3 \quad 1.36$

$4 \quad 1.44$

$5 \quad 1.48$

$7 \quad 1.54$

$9 \quad 1.58$

$12 \quad 1.62$

$15 \quad 1.66$

$20 \quad 1.73$

$25 \quad 1.78$

$30 \quad 1.84$

$35 \quad 1.88$

$40 \quad 1.93$

$45 \quad 1.97$

$50 \quad 2.00$

$60 \quad 2.06$

$75 \quad 2.15$

$90 \quad 2.23$

$105 \quad 2.30$

$120 \quad 2.35$

$150 \quad 2.46$

$180 \quad 2.54$

$210 \quad 2.61$

$240 \quad 2.67$

$300 \quad 2.76$

$360 \quad 2.86$

$420 \quad 2.93$

$540 \quad 3.03$

$660 \quad 3.10$

$780 \quad 3.17$

$900 \quad 3.22$

$1080 \quad 3.28$

$1320 \quad 3.34$

$1440 \quad 3.36$ 